IZA DP No. 4646

Exports, Imports and Wages:

Evidence from Matched Firm-Worker-Product Panels

Pedro S. Martins

Luca David Opromolla

December 2009 


\title{
Exports, Imports and Wages: Evidence from Matched Firm-Worker-Product Panels
}

\author{
Pedro S. Martins \\ Queen Mary, University of London, \\ CEG-IST and IZA \\ Luca David Opromolla \\ Banco de Portugal and UECE
}

Discussion Paper No. 4646

December 2009

\author{
IZA \\ P.O. Box 7240 \\ 53072 Bonn \\ Germany \\ Phone: +49-228-3894-0 \\ Fax: +49-228-3894-180 \\ E-mail: iza@iza.org
}

Any opinions expressed here are those of the author(s) and not those of IZA. Research published in this series may include views on policy, but the institute itself takes no institutional policy positions.

The Institute for the Study of Labor (IZA) in Bonn is a local and virtual international research center and a place of communication between science, politics and business. IZA is an independent nonprofit organization supported by Deutsche Post Foundation. The center is associated with the University of Bonn and offers a stimulating research environment through its international network, workshops and conferences, data service, project support, research visits and doctoral program. IZA engages in (i) original and internationally competitive research in all fields of labor economics, (ii) development of policy concepts, and (iii) dissemination of research results and concepts to the interested public.

IZA Discussion Papers often represent preliminary work and are circulated to encourage discussion. Citation of such a paper should account for its provisional character. A revised version may be available directly from the author. 
IZA Discussion Paper No. 4646

December 2009

\section{ABSTRACT \\ Exports, Imports and Wages: Evidence from Matched Firm-Worker-Product Panels*}

The analysis of the effects of firm-level international trade on wages has so far focused on the role of exports, which are also typically treated as a composite good. However, we show in this paper that firm-level imports can actually be a wage determinant as important as exports. Furthermore, we also find significant differences in the relationship between trade and wages across types of products. In particular, firms that increase their exports (imports) of high- (intermediate-) technology products tend to increase their salaries. Our analysis is based on unique data from Portugal, obtained by merging a matched firm-worker panel and a matched firm-transaction panel. Our data set follows the population of manufacturing firms and all their workers from 1995 to 2005 and allows for several control variables, including jobspell fixed effects.

JEL Classification: F16, J31, F15

Keywords: $\quad$ globalisation and labour, transaction data, wage differentials

Corresponding author:

Pedro Martins

School of Business and Management

Queen Mary, University of London

Mile End Road

London E1 4NS

United Kingdom

E-mail: p.martins@qmul.ac.uk

\footnotetext{
* We thank Mário Centeno, Carl Davidson, Steve Matusz, Álvaro Novo, Gary Solon, Maurizio Zanardi and seminar participants at Banco de Portugal, ETSG (Rome), Michigan State University and Queen Mary, University of London. We also thank Pedro Portugal for many thoughtful discussions and António Antunes and Lucena Vieira for computational assistance. The opinions expressed are those of the authors and not necessarily those of Banco de Portugal. Any errors are of our responsibility.
} 


\section{Introduction}

Some recent contributions to the understanding of the effects of international trade upon labour markets have focused on the role of exports on wages (Schank et al. 2007, Munch \& Skaksen 2008, Frias et al. 2009). Such emphasis on exports in these worker-level studies is warranted by new findings on the importance of firm heterogeneity in exports (Bernard \& Bradford Jensen 1999, Melitz 2003, Bernard \& Jensen 2004, Bernard et al. 2007) and also by ongoing research on the productivity effects of exporting (Clerides et al. 1998, Van Biesebroeck 2005, De Loecker 2007).

However, a deeper understanding of the effects of international trade upon labour markets requires the concurrent consideration of imports, the twin flow of exports. Indeed, this dimension of international trade - imports - has been conspicuously absent in the microlevel trade-and-labour literature, when one takes into account its huge potential impact as suggested by the following:

- Imports may matter more than exports in terms of their scope to affect welfare. As Krugman (1994) put it, '[T] he purpose of international trade - the reason it is useful - is to import, not to export. That is, what a country really gains from trade is the ability to import things it wants. Exports are not an objective in and of themselves.' Moreover, as the magnitude of imports is approximately equal to that of exports, imports clearly have a significant potential in terms of labour-market effects.

- Imports from developing countries have been regarded as a potentially major force driving the rising wage inequality observed in the U.S. and other countries Freeman (1995) reviews this literature). This view stemmed from the factor price equalisation result in international trade theory and the still large wage differences between developed and developing countries. Moreover, a recent literature has focused on the effects of outsourcing and offshoring (Kramarz $\mid 2008$, Hummels et al. 2009), two forces which can be important components of firm-level imports. Their emergence in the last decade has prompted concerns that the previous consensus of a relatively unimportant effect of international trade (and imports in particular) on wages may not longer apply (Krugman 2008).

- The export status of a firm is a good predictor of its import status Bernard \& Schott 
2009), implying that firm- or worker-level studies of the link between exports and wages that do not control for imports (Schank et al. 2007, Munch \& Skaksen 2008, Frias et al. 2009) may over- or underestimate the impact of exports. This missing-variable bias may also play some role in explaining the contrasting results of these studies ${ }^{1}$

- Finally, imports have recently been shown to generate important productivity effects, through channels involving learning, variety or quality aspects (Amiti \& Konings 2007. Goldberg et al. 2008, Halpern et al. 2009). In this context, it is possible that the increased profits resulting from the purchase of higher-quality intermediate inputs from foreign manufacturers be eventually shared with the firm's workers in terms of wages that exceed those workers' outside options. Such rent sharing would conceivably occur in labour markets that exhibit non-competitive features ${ }^{2}$

Our paper seeks to fill this considerable gap in the literature regarding the role of imports in wage determination. Specifically, this paper is the first that contrasts the roles of exports and imports in terms of firm- or worker-level wages. We implement our analysis drawing on rich matched firm-worker longitudinal data which we merge with rich firm-transaction longitudinal data - the latter including information on both exports and imports. This new data set follows the population of firms in a medium-sized open economy, Portugal, including all workers and all international trade transactions of each firm on an annual basis over a long period (1995 to 2005).

The richness of the data allows us to control for many confounding factors by estimating different econometric specifications, including worker and firm fixed effects or job spell fixed effects. In the latter specifications we rely on longitudinal variation in trade status or trade intensity in each firm to identify the effects of these variables on wages. This method ensures we are controlling for all (observed and unobserved) time-invariant factors that may be correlated with trade while also affecting wages. In addition, as the period covered by our data is centered at the introduction of the euro, it could be argued that our firms were exposed, at least in part, to an exogenous shock in terms of lower international transaction costs.

\footnotetext{
${ }^{1}$ Schank et al. (2007) and Munch \& Skaksen (2008) study the cases of Germany and Denmark, respectively, and find small or zero effects of exports, while Frias et al. (2009) studies the case of Mexico and finds large and significant effects.

${ }^{2}$ Overall, we believe this asymmetric treatment of exports and imports in the recent research results mainly from greater availability of exports data. Another factor that may play a role is that policy makers tend to be more interested in the effects of exports, even though, as mentioned in the Paul Krugman quote above, in a macroeconomic sense, exports are only of interest to the extent that they facilitate imports.
} 
Moreover, in a second contribution made in this paper, we test the implicit assumption from previous studies that all exports are the same in terms of their effects on wages, regardless of the type of products being sold. We also extend this analysis to the case of imports. The study of possible differences in the effects across product types is particularly useful as it can shed light on different (competitive or non-competitive) theoretical explanations for wage differentials amongst firms with different international trade statuses.

Our empirical results support the motivation of our analysis as we find that firm-level imports actually tend to be a determinant of wages as important as firm-level exports. Moreover, we also find that firms that increase their exports of high-technology products or that increase their imports of intermediate-technology products tend to increase their salaries, even after controlling for several other wage determinants.

The remaining of the paper is as follows: Section 2 discusses the main theoretical aspects of our analysis and some of the related literature, Sections 3 and 4 present the two data sets used and several descriptive statistics, Sections 5 and 6 present our results and, finally, Section 7 concludes.

\section{Theoretical discussion}

There are two main theoretical views one can appeal to in order to interpret any wage differences, in particular those among exporters, importers and non-traders which we study in this paper. In the first case, competitive views of the labour market would regard any wage premiums as a reflection of worker (unobserved) quality. For instance, econometric studies may draw on less information on workers than that available to employers when hiring, retaining or dismissing employees. In this case the wage premiums could correspond to systematic differences between the workforces in different types of firms and not to wages above the outside options of workers.

Similarly, wage differences could correspond to compensating differentials, for instance if the working conditions of firms that trade were disadvantageous compared to those of firms that do not trade. As an example, international traders may be subject to greater risk in terms of customer orders or production conditions, in which case workers would demand premiums. Alternatively, international traders may be able to achieve less risk through international diversification in their input and/or output markets, in which case workers would be willing 
to be paid less.

A second main theoretical view involves non-competitive mechanisms in the labour market. These typically evolve from search frictions or informational imperfections, for instance in terms of the matching between job-seekers and vacancies or in terms of the monitoring of worker effort. In the case of efficiency wages, firms that trade may require higher effort from their workers (see Verhoogen (2008) for the case of exporters). One example would be if consumers in destination countries value quality more than in the origin country. Firms that wish to export will then have to adjust the quality of their product mix and to motivate workers to exert more effort - for instance through wages that are sufficiently higher than the worker's best alternative 3

An alternative non-competitive mechanism that would generate a wage premium is rent sharing. In an important contribution, Kramarz (2008) emphasizes that importing can affect wages both because it changes the overall quasi-rent but also because it can affect the firms and the workers threat points when bargaining. There are a number of reasons why these threat points may change: for instance, imports of intermediate products may provide workers with hold-up opportunities when the firm has to purchase these inputs in advance. This might explain why importers pay more than non-importers (including exporters-only). However, imports of finished goods by the firm or by its competitors may weaken the employees' bargaining position if these imports result in a decrease of the workers' outside offers. Moreover, exporters may also need to make specific investments that would generate hold-up opportunities for their workers 4

A related point is that firms that trade may face different elasticities of demand of the products they sell. In particular, the elasticity of demand with respect to the product price may be higher for exporters than for non-exporters to the extent that the international market is more competitive than the domestic market. In this case, as indicated by Marshall's rules, exporters will be less prone to concede wage premia than importers.

In our view, the non-competitive models have a strong potential explanatory power given

\footnotetext{
${ }^{3}$ Moreover, firms that want to export might need to update their equipment and import better machines from abroad (Iacovone \& Javorcik (2008) show that the introduction of new export products tends to be preceded by investment in physical assets and technology acquisition). These firms might pay workers even more because the marginal benefit of convincing workers to exert more effort is higher due to the interaction of workers' effort with better machines.

${ }^{4}$ See also Amiti \& Davis (2008) who consider a model with fair wages, another non-competitive mechanism, where wages in the firm are proportional to firm's profits and not necessarily equal to the worker's outside option; and Davidson et al. (2008).
} 
the evidence that exporters are more productive than firms that sell only on the domestic market 5 In this case, exporters gain higher profits than non-exporters and might pass on some of those gains to their workers through some form of rent sharing.

Moreover, recent research on the productivity effects from international trade is placing emphasis on the role of importing too. To begin with, exporters are frequently importers as well (Bernard \& Schott 2009), in which case part of the productivity advantage of exporters can be due to their sourcing inputs from foreign markets (Altomonte \& Bekes 2009). In any case, either that of importers only or exporter-importers, access to cheaper imported inputs can again raise productivity via learning, variety, and quality effects Amiti \& Konings 2007, Kasahara \& Rodrigue 2008, Goldberg et al. 2008, Halpern et al. 2009). Importers arguably have greater choice in the sourcing of their inputs and can exploit any gaps between international and national prices, resulting in productivity or cost-efficiency differences.

Having reviewed the explanations above for either true or spurious wage premiums among importers and exporters when compared to non-traders, we underline that most if not all arguments apply equally to importers and exporters. However, the intensity of any worker heterogeneity or productivity effects may still vary depending on the specific trade status of the firm. In particular, importing and exporting may enhance a firm's profitability differently, particularly when products of different technological level are being transacted.

\section{The QP/INE data}

The data used in this paper are obtained from merging two major data sets: the INE trade data and the QP labour data. The INE trade data includes all export and import transactions by firms that are located in Portugal, on a monthly basis. These data are derived from customs returns forms in the case of extra-EU trade and from a special form supplied to the Portuguese statistics agency, INE - Instituto Nacional de Estatística (Intrastat) in the case of intra-EU trade. Overall, the data amount to the official total exports and imports of Portugal.

Each transaction record includes the firms tax identification, an eight-digit Combined Nomenclature product code, the value of the transaction, the quantity of transacted goods, the destination/origin country, the relevant international commercial term, etc. We were able

\footnotetext{
${ }^{5}$ Some research has argued that exporters are ex-ante more efficient and, as such, are able to sustain fixed and variable trade costs and self-select into export markets (Clerides et al. 1998). Other studies have shown that, on top of self-selection, exporters might become more productive because they learn from exporting (Van Biesebroeck 2005), especially when goods are sold to high-income countries (De Loecker 2007).
} 
to gain access for the purposes of this research to data from 1995 to 2005.

The second main data source is Quadros de Pessoal (QP), a longitudinal dataset matching firms and workers based in Portugal. The data are made available by the Ministry of Labour and Social Security, drawing on a compulsory annual census of all firms in Portugal that employ at least one worker. The data also cover individual information on all personnel working for each firm in a reference month (October), except for 2001. The variables available in the data set include the firm's location, industry, total employment, sales, ownership structure, and legal setting. At the worker's level, the data set includes information on gender, age, occupation, schooling, hiring date, earnings (five different variables), duration of work, etc.

Each firm entering the database is assigned a unique, time-invariant identifying number which we use to follow firms over time. Similarly, each worker also has a unique identifier, based on the worker's social security number, which we also use to follow individuals over time.

Finally, we merged the two data sets using the firm identifiers and firm characteristics made available in each data set. Given the predominance of manufacturing in international trade, we excluded from our analysis non-manufacturing sector firms. (See the data appendix for more details on the two data sets.)

\subsection{Descriptive statistics}

Table 1 presents aggregate descriptive statistics, on a year-by-year basis, based on the resulting data set. We find that the total number of firms (traders and non-traders) increases from 32,601 in 1995 to 39,071 in 2005, while the total number of employees falls from 817k in 1995 to $736 \mathrm{k}$ in 2005 . The latter development most likely reflects the increasing size of the services sector in Portugal as in most other developed economies.

More interestingly given our goals in this paper, the number of exporter-importers (exportersonly; importers-only) increases from 3056 (2104; 2015) in 1995 to 3725 (2538; 2154) in 2005. In terms of sales, there is also an increasing trend over time: by 2005, exports correspond to approximately $30 \%$ of total sales of the manufacturing sector, while imports correspond to about $25 \%$ of the same total sales. Overall, these statistics highlight the openness of the Portuguese economy, which has been a member of the European Union since 1986. Moreover, the greater percentages of exports and imports in terms of sales than in terms of number of 
firms is consistent with abundant evidence from other countries indicating that firms that trade are bigger than those that do not.

The special characteristics of traders can be discerned more clearly from Table 2, which presents several firm-level statistics, by international trade type (no trade, exporters-only, importers-only and exporters-importers), from pooled 1995-2005 data. As expected from the previous analysis, mean sales are much higher in the cases of traders than non-traders $(1.2 \mathrm{~m}$ euros or more vs $0.38 \mathrm{~m}$ ); moreover, sales of firms that both import and export are even higher, at more than $12 \mathrm{~m}$ euros. Mean firm size (in terms of number of workers) is again much higher in the case of traders (25 or more employees vs only 10), although less than proportionately in terms of the sales gap, suggesting greater productivity amongst traders.

Table 2 also presents different statistics concerning worker characteristics (first computed at the firm-year level and then averaged across firms and years). There are not major differences across firm types in terms of schooling or experience; however, firms that trade (in particular, firms that export) tend to exhibit a more feminine workforce and much higher levels of tenure. Furthermore, of particular interest for our study, we find that hourly wages are considerably higher at firms that trade than in firms that only sell at the domestic market: in the latter case the average real hourly wage is 3.12 euros per hour, while exporters-only (importers-only) pay 3.61 (4.43) and exporter-importers pay 4.67 euros per hour. Similar comparisons arise from the analysis of medians instead of means.

In addition, Table 2 presents descriptive information on the export and import shares (in terms of total sales) of each type of trader. We find that, on average, exporters-only sell $30 \%$ of their sales to foreign markets, while in the case of importers-only their international transactions correspond to $24 \%$ of their sales. For exporter-importers, the export and import shares are, respectively, $37 \%$ and $22 \%$. There is also evidence of skewness, as the median share is always smaller than the mean share.

Furthermore, we find from Figures 1 and 2 that there is a positive relationship between wages and exports and, in particular, imports, not only when considering the discrete measures of trade above but also when considering trade intensity: The slope of the fitted line of a simple bivariate regression of log wages on export (import) shares is .256 (.862), with a standard error of .011 (.017).

Finally, Table 3 presents worker-level descriptive statistics, again broken down by the 
international trade type of each worker's firm (no trade, exporters-only, importers-only and exporters-importers). This analysis addresses possible composition bias resulting from firmlevel averaging. However, we find that the rankings of the four types of firms across the different variables is typically unchanged. More importantly, we find again that workers employed in firms that trade are paid higher real hourly wages than their counterparts employed in firms that do not engage in international trade. Interestingly, we find again that the wage premium appears to be higher in the case of firms that only import than in the case of firms that only export (5.01 vs 3.66 euros per hour). Table 3 also makes clear the potential economylevel effects from the wage practices of firms that trade as they account for a large proportion of the manufacturing workforce: more than $4 \mathrm{~m}$ workers-year were employed by firms that export and/or import, compared to less than $2 \mathrm{~m}$ in the case of manufacturing-sector firms that do not trade.

\section{Trade dynamics}

As mentioned in the introduction, our analysis of the relationship between trade status and wages is based to a large extent on the variation over time of the firm's international trade. In this context, it is important to ascertain the actual level of variability in trade status and trade intensity of each firm over time. Moreover, it is also of general interest to understand in more detail whether trade status or intensity are largely time-invariant firm characteristics

- or, instead, if firms tend to switch into and out of export or import markets or if they vary such intensities frequently.

Table 4 presents a trade-status transition matrix, based on pooling our firm-level data over the 1995-2005 period. In each year, firms are assigned to one of five mutually-exclusive statuses: non-trader, exporter only, importer only, exporter-importer and outside the data ('out'). The last case concerns firms that enter the data (i.e. that are not in the data in year $t-1$ but are in the data in year $t$ - typically new firms) or firms that leave the data (i.e. that are present in year $t-1$ but not in year $t$ - typically bankruptcies or mergers). The 'total' column on the right-hand side sums horizontally the different outcomes in year $t$ conditional on a given status in year $t-1$.

From the analysis of the diagonal elements of Table 4, we find that a large percentage of firms, ranging from $57.3 \%$ to $79.5 \%$ of their $t-1$ category number stay in the same 
category in year $t$ (the exception, the 'out' category, is zero by construction). However, we also find that a considerable number of firms switch status, in particular if they are either exporter-only or importer-only in year $t-1$. For instance, $19.5 \%(8.4 \%)$ of exporters-only in $t-1$ become domestic (exporter-importer) in $t$. Similarly, $12.3 \%$ (9.8\%) of importers-only in $t-1$ become domestic (exporter-importers) in $t$. On the other hand, non-trader and exportimporter categories appear to be more 'permanent', particularly the former group: less than $2 \%$ of non-traders in year $t-1$ switch to a different category (except 'out') in year $t$, while less than $5 \%$ of exporter-importers in $t-1$ switch to either one of the three main status in $t$. These findings have to be borne in mind when interpreting our wage equation results based on specifications that draw on longitudinal variation in firms' trade status.

As mentioned above, there is evidence of dispersion in trade intensities even within each type of trader. Figure 3 sheds some additional light on this by presenting a scatterplot of the joint distribution of export and import shares. (Given the very large size of our data, this scatterplot is based on a $10 \%$ random sample of the entire data.) We find that, while there are large numbers of firms along the horizontal (import/sales ratio) or vertical (export/sales ratio) axes - i.e. firms that either only import or only export -, there is also a considerable spread across firms, in particular in terms of the latter dimension. A related result is that, perhaps not surprisingly, only a very small number of firms import large shares of their sales, for instance of more than $75 \%$.

Following up on this preliminary analysis, which indicates a considerable amount of crosssectional variation, Figure 4 presents a scatterplot of the joint distribution of changes in export and import shares, drawing on the same sample as the one used for Figure 3 . We find again a considerable amount of variation across firms. Moreover, there is no particular predominance of a particular direction in the export or import shares, as all quadrants exhibit similarly large numbers of firm-year observations.

We also extend our analysis of the extent of firm status variation to the worker level for the same descriptive and identification reasons as above. From the consideration of the diagonal elements of the top panel of Table 5, we find that a large number of workers, ranging from $41.3 \%$ to $65.3 \%$ of their $t-1$ category total size stay in the same category in year $t$ (again, the exception, the 'out' category, is zero by construction). However, we also find that a considerable number of workers switch status, in particular if they are employed in firms 
that trade in year $t-1$. For instance, $11 \%$ of workers employed in exporters-only in $t-1$ are employed in either exporter-importers or domestic firms in year $t$. Similarly, $7 \%(11.2 \%)$ of workers employed in importers-only in $t-1$ are employed in domestic (exporter-importers) firms in $t$. On the other hand, employment in domestic and export-importer firms appears to be more time-invariant, given that less than $3 \%$ of those workers in year $t-1$ switch to any other category (except 'out') in year $t .6$

In addition, as some of the models that we will estimate in the next two sections draw on variation within (employer-employee) spells, we also investigate the amount of variability in trade status for worker-year pairs in which the worker is employed in the same firm in years $t-1$ and $t$. The bottom panel of Table 5 presents this transition matrix. As one may expect, we find that disregarding between-firm movers reduces the extent of trade status variability. Indeed, from the analysis of the diagonal elements of Table 5, we find that a large number of workers, ranging from $66.1 \%$ to $94.4 \%$ of all workers in each $t-1$ category stay in the same category in year $t$. However, even within matches there is a non-ignorable amount of trade status variation, in particular for workers employed in either exporter-only or importer-only firms: between $10 \%$ and $16 \%$ of these workers (in terms of their $t-1$ status) move into domestic firms, while $16 \%$ move into exporter-importer firms (in $t$ ).

Finally, we consider the variation in trade status at the firm level but over a longer period. In particular, we examine the years 2002-2005 and document the most important trade status paths, defined as a given combination of trade status over the four years. When not weighting for firm size, we find - see top panel of Table 6- that the most common pattern corresponds to firms that are non-traders all four years (15,698 firms). However, the second most common pattern corresponds to firms that are always exporter-importers, although at a large distance (1,999 firms only). Moreover, the third and fourth most important patterns are always importer-only (744) and always exporter-only (602). Only when we get to the fifth most common pattern do we observe firms that switch their status: always non-traders that become exporters in 2005 (289 firms) or exporters than become non-traders in 2003 (217). A large number of other combinations then follows, including 2752 firms whose combinations are outside the top-10 patterns listed.

We also consider the diversity of patterns when weighting firms by their employment size -

\footnotetext{
${ }^{6}$ Mobility into or out of the 'out' category includes workers that remain in the QP data set but are employed in a non-manufacturing firm. Other cases include retirement, inactivity, unemployment or workers whose identifiers have been coded incorrectly.
} 
see the bottom panel of Table6. We find again that the most important time patterns are those in which the trade status is unchanged over the four-year period we consider. However, now the most important specific pattern corresponds to firms that are always exporter-importers (representing an average of $188 \mathrm{k}$ workers), followed by always non-traders (104k). Always importers (19k) and always exporters (9k) come next, but only after a big gap in terms of the number of workers involved. The other most important patterns in terms of our top-10 ranking are firms that switch from importers-only to exporters-importers and non-traders that become exporters. As in the case of the un-weighted analysis, we find that 'flip-flopping' patterns, in which firms switch back and forth in their trade status, are not empirically important.

Overall, we conclude from this analysis that there is considerable scope for (statistical) identification of models that rely on variation in firm trade status or even trade intensity. However, results based on within-spell variation will need to take into account that such variation is less widespread, with possible effects in terms of the precision of the resulting estimates.

\section{$5 \quad$ Main results}

The main goal of this paper is to assess and compare the effects of exporting and importing in terms of workers' pay. Our analysis is based on the estimation of wage equations, including a varying and - in some specifications - particularly large set of control variables, including firm and/or worker fixed effects or firm-worker spell fixed effects. The identification of the effects of interest is therefore based on the assumption that, given such large set of controls, variation across observations in trade status or trade intensity is random.

We begin by estimating our wage equations on firm-level data, given the benchmark set by the earlier literature; and then move on to worker-level data, in order to take into account compositional biases that may affect the firm-level analysis. 


\subsection{Firm-level analysis}

Our first set of results are obtained by estimating different versions of the following wage equation:

$$
\begin{array}{r}
y_{j t}=\beta_{1}(\text { Exporter }- \text { only })_{j t}+\beta_{2}(\text { Importer }- \text { only })_{j t}+\beta_{3}(\text { Exporter }- \text { Importer })_{j t}+ \\
W_{j t}^{\prime} \beta_{4}+F_{j t}^{\prime} \beta_{5}+\tau_{t}+\gamma_{j}+\epsilon_{j t},
\end{array}
$$

in which $y_{j t}$ is the logarithm of the mean real hourly total wage of firm $j$ in year $t$. (Exporter$o n l y)_{j t},(\text { Importer - only })_{j t}$ and (Exporter - Importer $)_{j t}$ are the explanatory variables of interest, dummy variables equal to one if firm $j$ only exports, only imports or both exports and imports, respectively, in year $t . F_{j t}$ and $W_{j t}$ are a vector of firm and (average) worker control variables, respectively, and $\tau_{t}$ and $\gamma_{j}$ are year and firm fixed effects, respectively.

Given that most of the literature has considered only the role of exports on wages, we begin by estimating a version of equation 3 that excludes all trade dummies and redefines the Exporter dummy as taking value one if the firm exports (regardless of its import status). Table 7 reports the results, considering four different specifications, each based on different sets of controls variables. From this analysis, we find that, either with just year fixed effects (column 1) or when controlling also for (average) worker characteristics (schooling, quadratics in experience and tenure, gender and hours - column 2), there is a very large and precisely estimated export premium, as the $\beta_{1}$ estimates are .255 and .191, respectively (columns 1 and 2). However, this coefficient falls considerably, to .057 when including firm controls (firm size, foreign ownership, and region and industry dummies) - see column 3 - and to .007 when adding firm fixed effects (column 4) 7 These results indicate that a large part of the export wage premium is explainable by the different (time-varying and time-invariant) characteristics of firms that export.

We now turn to the estimates from equation 3 , which we present in Table 8 . Consistently with the evidence from the descriptive statistics, we find that, when ignoring all control variables, exporter-importer and importer-only status result in the highest average wage, with coefficients of .368 and .312 , respectively. Exporters-only exhibit a coefficient of less than half, .14. The comparison of these results with the same specifications from Table 7 -

\footnotetext{
${ }^{7}$ Amongst such different firm characteristics, the role of foreign ownership has received attention in the literature, including the case of Portugal (Martins 2004, forthcoming).
} 
without separating betwee exporters-only and exporter-importers - is interesting. Indeed, the big fall in the export coefficients (from .255 to .140) indicates that much of the large effect from the first table comes from the considerable number of exporters that also import and their high wages.

Columns 3 and 4 of Table 8 include firm controls and, as in Table 7, we find that the until then still very large export coefficient drop considerably. However, the importer coefficient remains larger than its exporter counterpart (at .017 vs .009), while exporter-importers exhibit a coefficient of .019 (column 4).

As suggested before, a better understanding of the relationship between wages and international trade requires an analysis along both the extensive and intensive margins. We therefore now turn to the estimation of a different version of equation 3 , in which we replace the trade status dummies by two continuous variables, $\mathrm{X} / \mathrm{S}$ and $\mathrm{M} / \mathrm{S}$, the export and import shares in terms of total sales:

$$
y_{j t}=\beta_{1}^{*}(X / S)_{j t}+\beta_{2}^{*}(M / S)_{j t}+W_{j t}^{\prime} \beta_{3}^{*}+F_{j t}^{\prime} \beta_{4}^{*}+\tau_{t}+\gamma_{j}+\epsilon_{j t},
$$

in which all the variables are defined in the same way as in equation 3 and $S$ denotes the level of sales (of firm $j$ in year $t$ ). The key explanatory variables, $(X / S)_{j t}$ and $(M / S)_{j t}$ are continuous variables. They vary along the interval $[0,1]$ in the case of the export share and in the range $[0,10]$ in the case of the import share, even if, as mentioned before, very few firms import more than their sales.

For comparison purposes, Table 9 presents the results based on a specification that ignores imports, i.e. in which the only trade-related variable is the share of exports in total sales. Again we find a similar pattern to the results in Table 7, as the specifications without firm controls results in large wage premiums, of around $.25 \mathrm{log}$ points in the two first columns. Moreover, the coefficients again drop considerably when firm controls are included, to .031 in the specification with worker and firm controls and to .013 in the specification that also includes firm fixed effects.

Finally, we turn to Table 10 which adds the import share to the wage equation. We find that, as before, the export coefficient drops (about .05 log points in this case) when a control for imports is added. More importantly, the results indicate that the effect of the import share is much larger than that of the export share, at .436 (without controls) and .284 (with 
worker controls), compared with the corresponding export-share coefficients of .198 and .205, respectively. In addition, again as in the specification based on trade status (Table 8), the main coefficients become very small in the most comprehensive model of column 4 , which also includes both firm controls and firm fixed effects.

We conclude from our firm-level analysis that the exporter and importer premiums fall to less than .02 when firm controls (including firm fixed effects) are taken into account. On the other hand, we find that if not considering the most stringent specifications - in particular when not controlling for time-invariant heterogeneity - the importer premium is generally much larger than its exporter counterpart.

\subsection{Worker-level analysis}

After establishing the importance of exports and imports in terms of a firm-level analysis, we now take our estimations to the worker level. This allows us to address more directly any compositional biases that may explain the firm-level results. For instance, when firms begin importing or exporting they may also adjust their hiring policies towards more skilled employees. Although we already control for several human capital and other variables, such differences in personnel quality over time may still be obscured in the data in such a way that a premium is estimated even if such wage differential can actually be accounted for by worker quality differences. By following each worker over time, we minimise such potential bias.

Specifically, in this subsection we estimate different versions of the following wage equation:

$$
\begin{array}{r}
y_{i j t}=\beta_{1}(\text { Exporter }- \text { only })_{i j t}+\beta_{2}(\text { Importer }- \text { only })_{i j t}+\beta_{3}(\text { Exporter }- \text { Importer })_{i j t}+ \\
W_{i j t}^{\prime} \beta_{4}+F_{j(i, t), t}^{\prime} \beta_{5}+\tau_{t}+\alpha_{i}+\gamma_{j}+\epsilon_{i j t},
\end{array}
$$

in which $y_{i j t}$ is logarithm of the real hourly total wage of worker $i$ in firm $j$ in year $t$, $(\text { Exporter - only })_{i j t},(\text { Importer - only })_{i j t}$ and $(\text { Exporter - Importer })_{i j t}$ are the explanatory variables of interest, dummy variables equal to one if worker $i$ is employed in year $t$ in a firm $j$ that exports only, imports only or exports and imports, respectively. $W_{i j t}$ and $F_{j(i, t), t}$ are a vector of worker and firm control variables, respectively, and $\tau_{t}, \gamma_{j}$ and $\alpha_{i}$ are time, firm and worker fixed effects, respectively.

In order to fully compare our findings with those from the firm-level analysis, Table 11 
presents results from a specification that considers only the export status (a dummy equal to one if the firm exports, regardless of its import status). Consistently with Table 7, we find again, in columns 1 and 2, that workers employed by firms that export are paid considerable premiums, of between .234 and .151 log points, in specifications either without controls or with worker controls only. However, again as before, the inclusion of firm controls reduces significantly the estimates, generally to point estimates of less than .01, even if in some specifications these are significant.

Two specifications are entirely new (when compared to the firm-level results) and deserve special attention. First, the specification in column 6 is based on the joint estimation of worker and firm fixed effects. As it is well-known in this literature (Abowd et al. 1999), such estimation requires mobility of workers between firms in order to disentangle the two types of effects and computational power to handle the large data sets in which such mobility is present in a meaningful way, such as the one used in this paper. We address this estimation matter by drawing on the algorithm put forward by Guimaraes \& Portugal (2009) 8

Second, the specification in column 7 is also important as it relies on spell (worker-firm match) fixed effects. This means that in this case the only source of variation used for the purpose of the estimation of the export (and, later, the import) variables is the variation within such matches. However, as we have concluded before, when discussing the workerlevel transition matrix for workers that stay in the same firm - second part of Table 5 -, this variability is somewhat limited when compared to the case of the entire manufacturing population.

Having highlighted these important identification and estimation issues, we now turn to Table 12, which includes both export, import and export-import trade status. Columns 1 and 2, which exclude firm controls, are again consistent with the firm-level analysis in that the import coefficient proves to be much larger than its export counterpart (.278 vs .054 in column 1, .151 vs .059 in column 2). Moreover, as before, the exporter-importer coefficient is larger than both the exporter-only and importer-only coefficients (.333 and .209 in columns 1 and 2 , respectively).

When considering the different specifications with firm controls, we find that, once again, the point estimates fall considerably, in many cases dropping to less than .02. However, as

\footnotetext{
${ }^{8}$ See Carneiro et al. (2009) for an application, also based on the QP data set. The $R^{2}$ statistic is not strictly comparable with those of the other specifications.
} 
before, the import variable is more resilient to the different controls. Column 6 , based on the specification with firm and worker fixed effects, is particularly interesting in this respect, as all trade coefficients are significant, even at the $1 \%$ level.

Finally, we turn to the specifications based on a continuous measurement of the trade variables:

$$
y_{i j t}=\beta_{1}^{*}(X / S)_{j(i, t), t}+\beta_{2}^{*}(M / S)_{j(i, t), t}+W_{i j t}^{\prime} \beta_{3}^{*}+F_{j(i, t), t}^{\prime} \beta_{4}^{*}+\tau_{t}+\gamma_{j}+\epsilon_{i j t}
$$

following a similar notation as in the previous equations.

First we consider Table 13, which examines only the share of exports in total sales in isolation. Here we find, as in the firm-level analysis, that before controlling for firm characteristics, there is a statistically significant and positive relationship between export intensity and sales but this relationship turns much weaker (and, in some cases, insignificant) when firm-level controls are added. However, contrary to the firm-level results, our worker-level analysis documents a statistically significant and positive relationship when firm fixed effects are added: for instance, in column 6, when both firm and worker fixed effects are considered, we find a coefficient of .026 , significant at the $1 \%$ level. This coefficient remains positive and at a similarly small magnitude (.018) when spell fixed effects are considered instead; however, the coefficient is no longer significant.

Having established the importance of exports following previous research based on similar specifications (Schank et al.|2007, Munch \& Skaksen|2008), we now turn to a novel specification that considers the roles of both export and import intensities. Table 14 presents these results. We find that, when not controlling for firm characteristics, the share of imports plays a much important role on wages that its export equivalent. For instance, column 2 (which includes only workers controls), indicates that the import share coefficient is .238, compared to only .056 for the case of exports (both significant at the $1 \%$ level).

More importantly, we also find that in many of the remaining specifications, the point estimate of the imports variable is larger and/or more significant than its export counterpart. For instance, when controlling for worker fixed effects, the imports share coefficient is .012 and significant at the $5 \%$ level, while the export share estimate is -.006 and insignificant. However, the point estimates and their precision turn out to be very similar when controlling for both worker and firm fixed effects. In the end, imports appear to be a determinant of wages of a 
similar importance than exports.

\section{$6 \quad$ Extensions}

\subsection{Differences by products}

In order to test further the robustness of our main resuls, this section decomposes each firm's exports and imports in terms of the technological level of the products transacted. This analysis is also relevant given our theoretical motivation, in which we underlined the role of productivity effects from exports and/or imports in terms of the creation of wage premiums. Indeed, products of different technological level may generate different productivity - and therefore wage - effects. Another related aspect was the role of efficiency wages in the improvement of product quality.

Specifically, in this section we divide all traded products into four categories, low, mediumlow, medium-high and high technology, following an OECD sectoral classification. Table 15 presents the distribution of exports and imports (in terms of their total value) across product types. We also include detailed information of the products in each category. This table indicates a balanced distribution of exports and imports across the four product categories, except for a larger share of transactions at lower-technology goods, particularly in terms of exports, which account for $43.9 \%$ of all exported goods.

Figures 5 and 6 illustrate the relationship between export and import shares of products of different technological levels and their firms' unconditional wages. An eyeball examination of these figures suggests that wages increase particularly with medium- and high-tech export intensities and import intensities of all technological levels. However, in some cases, the positive relationship between trade intensities and wages may be driven by a relatively small number of firms.

We then turn to the wage equation estimates. These results are based on the specification that considers the intensive margins of either exports only or both exports and imports, now broken down in four types of products (following the structure of equation 4). Table 16 presents the results that consider the role of exports (in total sales by product type) only, using firm-level data. The first column, which ignores all control variables, indicates considerable differences across product types. For instance, while low-tech exports translate into a wage increase of only .09, high-tech exports correspond to a wage increase of .886. More generally, 
there is a positive relationship between the wage premium and the technological level of the product. However, when one takes into account the possible correlations of different firm characteristics and the average level of technological sophistication of the product exported, one finds that the wage gradient flattens considerably. On the other hand, these is still some evidence of greater wage effects from medium- and high-tech goods even in the specification with firm fixed effects (column 4).

A similar set of results is found when we take into account both the breakdown of exports and imports in terms of their technological levels - Table 17. However, a major difference between exports and imports is that the relationship of the latter with wages seem to humpshaped, as the highest effect arises with medium-high tech products.

Finally, we replicate the analysis above considering worker-level data. Table 18 presents the results based on the analysis of the share of exports in total sales by product type. As before, when considering the firm-level analysis of this same specification, we find a steep increase in wage premiums with the technological level of the product exported, at least between the first three levels. Moreover, the addition of more control variables flattens the relationship considerably. However, even when controlling for both worker and firm fixed effects, we find a clear upward pattern between the wage premiums and the technological level of exports (.011 for low-tech, .035 for medium-low, .037 for medium-high, and .057 for high-tech products, all statistically significant at the $1 \%$ level). Furthermore, even in the most demanding specification, based on spell fixed effects, the exports of highest-technology products is significantly related to higher wages, with a point estimate of .071 .

This result proves to be robust to the inclusion of similar controls for the imports of each worker's firm. Table 19 reports a very similar point estimate, of .072, in the same spell fixed effects specification. However, while we find a similar wage gradient with the technological level of imports in the specifications without control variables, ultimately the wage premium is highest or only significant for imports of intermediate technological level (medium-low and medium-high products in the specification with worker and firm fixed effects).

\subsection{Robustness tests}

We have also tested the robustness of our results by replicating our analysis (firm- and workerlevels, considering aggregate products or products of different technological level) under dif- 
ferent specifications and sample definitions. In the first test, we included sales in the list of firm control variables. The motivation is that it is well known that rent sharing can be an important component of wage determination. We found from this analysis (results not reported but available upon request) that imports become even more important when controlling for sales. This result can be seen as consistent with the effect of threat points.

In another set of tests, we redid our regressions including a control for equity, a proxy for capital available in our data. We found that all our results are robust to the inclusion of this variable. This finding suggests that the roles of exports and imports upon wages are not simply capturing differences across firms in terms of their capital intensity.

We also considered different subsets of our original data, in order to create more comparable group of firms, less subject to biases driven by differences in their common support: only firms with more than 50 employees, only firms with total sales higher than 100.000 euros, only workers with tenure greater than five years, or only Portuguese firms. The last data subset is of particular importance, as it addresses the potential criticism that foreign firms reports of their international trade may be subject to transfer pricing, which could bias the effects from trade levels on wages that we document. However, we find in all subsets the same qualitative results as in our benchmark findings.

Finally, we also considered different wage measures, in particular only base pay, thus disregarding the other components which we include in our baseline specifications - overtime pay (and overtime hours), tenure-related pay and bonuses. Once again our benchmark results proved robust.

\section{Conclusions}

Recent contributions to the trade-and-wages literature have focused exclusively on the role of exports. For several reasons, we see this focus on exports to the detriment of imports as an important shortcoming in the understanding of the effects of international trade upon labour markets. Our paper addresses this gap by drawing on unique data from Portugal, merging two different matched panel data sets, and providing the first comparative analysis of the roles of exports and imports on wages.

Our results indicate that imports tend to be a determinant of wages at least as important as exports. This finding is robust across a large range of econometric specifications and ap- 
plies at both the firm- and worker-levels. However, the wage premiums can exhibit a small economic magnitude, although typically only in the most demanding econometric specifications (spell fixed effects). Indeed, in our analysis, such specification controls not only for all time-invariant heterogeneity but also for a considerable amount of time-varying firm and worker heterogeneity. As it is therefore quite unlikely that such stringent estimates are picking up worker quality differences across firms of different trading status, we interpret our results (small but non zero estimates) as indicating that non-competitive labour-market mechanisms are present amongst both importers and exporters.

In terms of our theoretical discussion, the importance of imports in terms of wages can be reconciled with different views, including productivity effects from imports as in the case of exports. The interpretation based on the productivity effect of trade is also consistent with our current research (Martins \& Opromolla 2009), which uses a similar data set to the one presented here to examine the relationship between exports and imports in terms of labour productivity. Our preliminary results indicate that productivity increases systematically when firms engage in either exporting and importing.

Moreover, we also find evidence against the practice so far common in the literature of treating exports as a composite good. In fact, our results indicate that there are important differences in the relationship between exports - and also between imports - and wages across product types. In particular, firms that increase their exports of high-technology products or that increase their imports of intermediate-technology products tend to increase their pay the most. This difference between importers and exporters can tentatively be explained taking into account that the economy under study here, Portugal, although developed, is typically below the international technological frontier in several sectors. Therefore, imports of products of an intermediate technological level may be those more likely to improve firms' performance, as high-tech products may hit absorption capacity constraints. On the other hand, and more generally, high-tech exports will tend to be more differentiated and subject to lower price-demand elasticities in destination markets, leading to rents that can subsequently be shared with employees. High-tech exports (medium-tech imports) may also result from efficiency-wage policies adopted by exporters (importers) keen to upgrade the technological level of their products. 


\section{References}

Abowd, J. M., Kramarz, F. \& Margolis, D. N. (1999), 'High wage workers and high wage firms', Econometrica 67(2), 251-334.

Altomonte, C. \& Bekes, G. (2009), Trade complexity and productivity, Bocconi University mimeo.

Amador, J. \& Opromolla, L. D. (2008), Product and destination mix in export markets, Working Paper 17-2008, Banco de Portugal.

Amiti, M. \& Davis, D. R. (2008), Trade, firms, and wages: Theory and evidence, NBER Working Paper 14106.

Amiti, M. \& Konings, J. (2007), 'Trade liberalization, intermediate inputs, and productivity: Evidence from indonesia', American Economic Review 97(5), 1611-1638.

Bernard, A. B. \& Bradford Jensen, J. (1999), 'Exceptional exporter performance: cause, effect, or both?', Journal of International Economics 47(1), 1-25.

Bernard, A. B. \& Jensen, J. B. (2004), 'Why some firms export', Review of Economics and Statistics 86(2), 561-569.

Bernard, A. B., Jensen, J. B., Redding, S. J. \& Schott, P. K. (2007), 'Firms in international trade', Journal of Economic Perspectives 21(3), 105-130.

Bernard, A., J. J. \& Schott, P. (2009), chapter Importers, Exporters and Multinationals: A Portrait of Firms in the U.S. that Trade Goods.

Cabral, L. \& Mata, J. (2003), 'On the evolution of the firm size distribution: Facts and theory', American Economic Review 93(4), 1075-1090.

Carneiro, A., Guimaraes, P. \& Portugal, P. (2009), Real wages and the business cycle: Accounting for worker and firm heterogeneity, IZA Discussion Papers 4174.

Clerides, S. K., Lach, S. \& Tybout, J. R. (1998), 'Is learning by exporting important? Microdynamic evidence from Colombia, Mexico, and Morocco', Quarterly Journal of Economics 113(2), 903-947. 
Davidson, C., Matusz, S. J. \& Shevchenko, A. (2008), 'Globalization and firm level adjustment with imperfect labor markets', Journal of International Economics 75(2), 295-309.

De Loecker, J. (2007), 'Do exports generate higher productivity? Evidence from Slovenia', Journal of International Economics 73(1), 69-98.

Freeman, R. B. (1995), 'Are your wages set in Beijing?', Journal of Economic Perspectives $\mathbf{9}(3), 15-32$.

Frias, J. A., Kaplanz, D. S. \& Verhoogen, E. A. (2009), Exports and wage premia: Evidence from Mexican employer-employee data, Columbia University mimeo.

Goldberg, P. K., Khandelwal, A., Pavcnik, N. \& Topalova, P. (2008), Imported intermediate inputs and domestic product growth: Evidence from India, NBER Working Paper 14416.

Guimaraes, P. \& Portugal, P. (2009), A simple feasible alternative procedure to estimate models with high-dimensional fixed effects, IZA Discussion Paper 3935.

Halpern, L., Koren, M. \& Szeidl, A. (2009), Imports and productivity, University of California, Berkeley mimeo.

Hummels, D., Jorgensen, R., Munch, J. \& Xiang, C. (2009), The wage and employment effects of outsourcing: Evidence from Danish matched worker-firm data, Purdue University mimeo.

Iacovone, L. \& Javorcik, B. (2008), Multi-product exporters: Diversification and micro-level dynamics, World Bank Working Paper 4723.

Kasahara, H. \& Rodrigue, J. (2008), 'Does the use of imported intermediates increase productivity? Plant-level evidence', Journal of Development Economics 87(1), 106-118.

Kramarz, F. (2008), Offshoring, wages, and employment: Evidence from data matching imports, firms, and workers, CREST-INSEE mimeo.

Krugman, P. (1994), Competitiveness: Does it matter?, Fortune magazine.

Krugman, P. (2008), Trade and wages, reconsidered, Brookings Papers on Economic Activity.

Loschky, A. (2008), Reviewing the nomenclature for high-technology trade - the sectoral approach, Working Paper STD/SES/WPTGS(2008)9. 
Martins, P. \& Opromolla, L. D. (2009), Exports, imports and firm performance, Banco de Portugal mimeo.

Martins, P. S. (2004), Do foreign firms really pay higher wages? Evidence from different estimators, IZA Discussion Paper 1388.

Martins, P. S. (2009), 'Dismissals for cause: The difference that just eight paragraphs can make', Journal of Labor Economics 27(2), 257-279.

Martins, P. S. (forthcoming), 'Paying more to hire the best? Foreign firms, wages and worker mobility', Economic Inquiry .

Melitz, M. J. (2003), 'The impact of trade on intra-industry reallocations and aggregate industry productivity', Econometrica 71(6), 1695-1725.

Munch, J. R. \& Skaksen, J. R. (2008), 'Human capital and wages in exporting firms', Journal of International Economics 75(2), 363-372.

Schank, T., Schnabel, C. \& Wagner, J. (2007), 'Do exporters really pay higher wages? First evidence from German linked employer-employee data', Journal of International Economics $\mathbf{7 2}(1), 52-74$.

Van Biesebroeck, J. (2005), 'Exporting raises productivity in sub-Saharan African manufacturing plants', Journal of International Economics 67(2), 373-391.

Verhoogen, E. A. (2008), 'Trade, quality upgrading, and wage inequality in the Mexican manufacturing sector', Quarterly Journal of Economics 123(2), 489-530.

\section{Appendix: Data}

\section{A. INE trade data}

The INE trade data includes all export and import transactions by firms that are located in Portugal, on a monthly basis. These data are derived from customs returns forms in the case of extra-EU trade and from a special form supplied to the Portuguese statistics agency, INE Instituto Nacional de Estatística (Intrastat) in the case of intra-EU trade. Firms are required to provide information on their trade transactions if the volume of exports or imports in the previous year or two years before was higher than 60,000 euros and 85,000 euros respectively. Overall, the data amount to the official total exports and imports of Portugal. 
Each transaction record includes the firms tax identification, an eight digit Combined Nomenclature product code, the value of the transaction, the quantity of transacted goods (expressed in kilograms), the destination/origin country, the type of transport, the relevant international commercial term (FOB, CIF, etc) and a variable indicating the type of transaction (transfer of ownership after payment, return of a product, etc). Also see Amador \& Opromolla (2008) for more information about the data and several descriptive statistics.

\section{B. QP labour data}

Quadros de Pessoal (QP), a longitudinal dataset matching firms and workers based in Portugal. The data are made available by the Ministry of Labour and Social Security, drawing on a compulsory annual census of all firms in Portugal that employ at least one worker. The data also cover individual information on all personnel working for each firm in a reference month (October), except for 2001.

The administrative nature of the data and their public availability at the workplace - as required by law - imply a high degree of coverage and reliability. See, amongst other papers, Cabral \& Mata (2003) and Martins (2009) for recent applications based on the QP data. Our sample includes all manufacturing firms based in Continental Portugal and their full-time employees, age between 16 and 65, working a minimum of 25 and a maximum of 80 total hours per week.

The variables available in the data set include the firm's location, industry, total employment, sales, ownership structure (foreign, domestic private and domestic public), and legal setting. At the worker's level, the data set includes information on gender, age, occupation, schooling, hiring date, earnings (five different variables), duration of work (three different variables), as well as information abot collective bargaining.

The mean wage is computed adding base and overtime wages plus tenure- and performancerelated compensation and dividing by the number of regular and overtime hours worked in the reference month. Sales, exports and imports are expressed in 2004 billion euros. Gross wages are deflated by the Consumers Price Index (made available by INE) to 2004 euros.

We classify firms are foreign-owned if they have a foreign participation in their equity of at least $50 \%$. $78 \%$ of the firms in our sample with a non-zero foreign ownership meet this threshold.

Personnel on short-term leave (such as sickness, maternity, strike or holidays) are included, whereas personnel on long-term leave (such as military service) are not reported. Civil servants, the self-employed and domestic service are not covered, and the coverage of agriculture is low given its low share of wage-earners.

\section{HS and OECD Nomenclatures}

The Combined Nomenclature system is comprised of the Harmonized System (HS) nomenclature with further European Community subdivisions. The HS is run by the World Customs Organisation (WCO). This classification of commodities is used by most trading nations and in international trade negotiations. The first six digits of the Combined Nomenclature system approximately coincide with the HS classification. While the Combined Nomenclature system is changed almost every year, the HS, created in 1988, was updated on January 1st 1996, January 1st 2002 and January 1st 2007.

The OECD nomenclature (Loschky 2008) takes into account both the level of technology specific to the sector (measured by the ratio of $R \& D$ expenditure to value added) and the technology embodied in purchases of intermediate and capital goods. We then converted this sectoral classification into a product classification. 
When creating the export and import shares, we ignore both firm-years' export shares in which that ratio is greater than one and firm-years' import shares in which that ratio is greater than 10. Each one of these cases correspond to a very small percentage of our observations. 


\section{Figures}

Figure 1: Export shares and wages

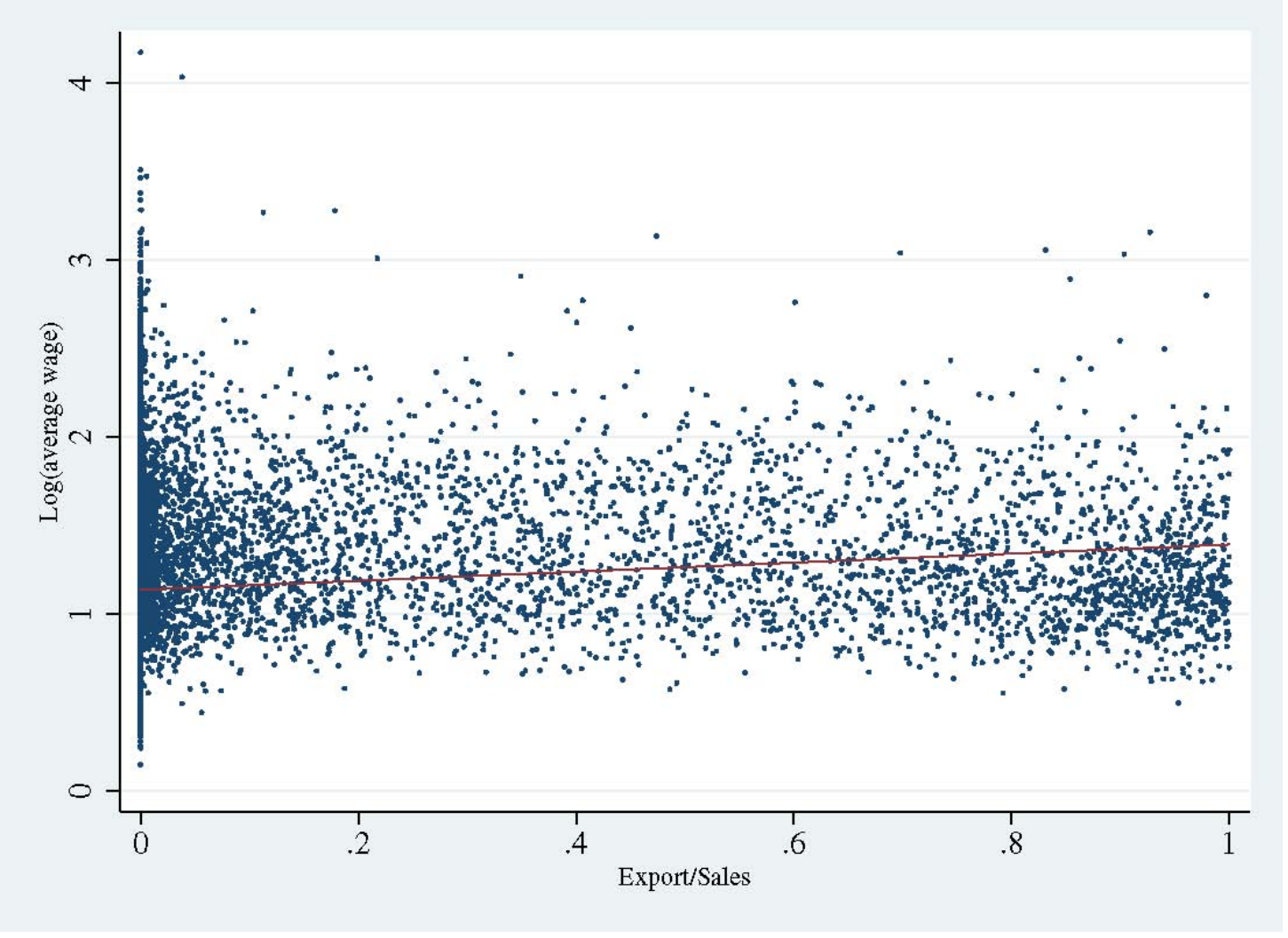

Note: Source: Authors calculations based on Quadros de Pessoal and INE trade data. Representative 10\% sample of all 1995-2005 pooled firm-level data. 
Figure 2: Import shares and wages

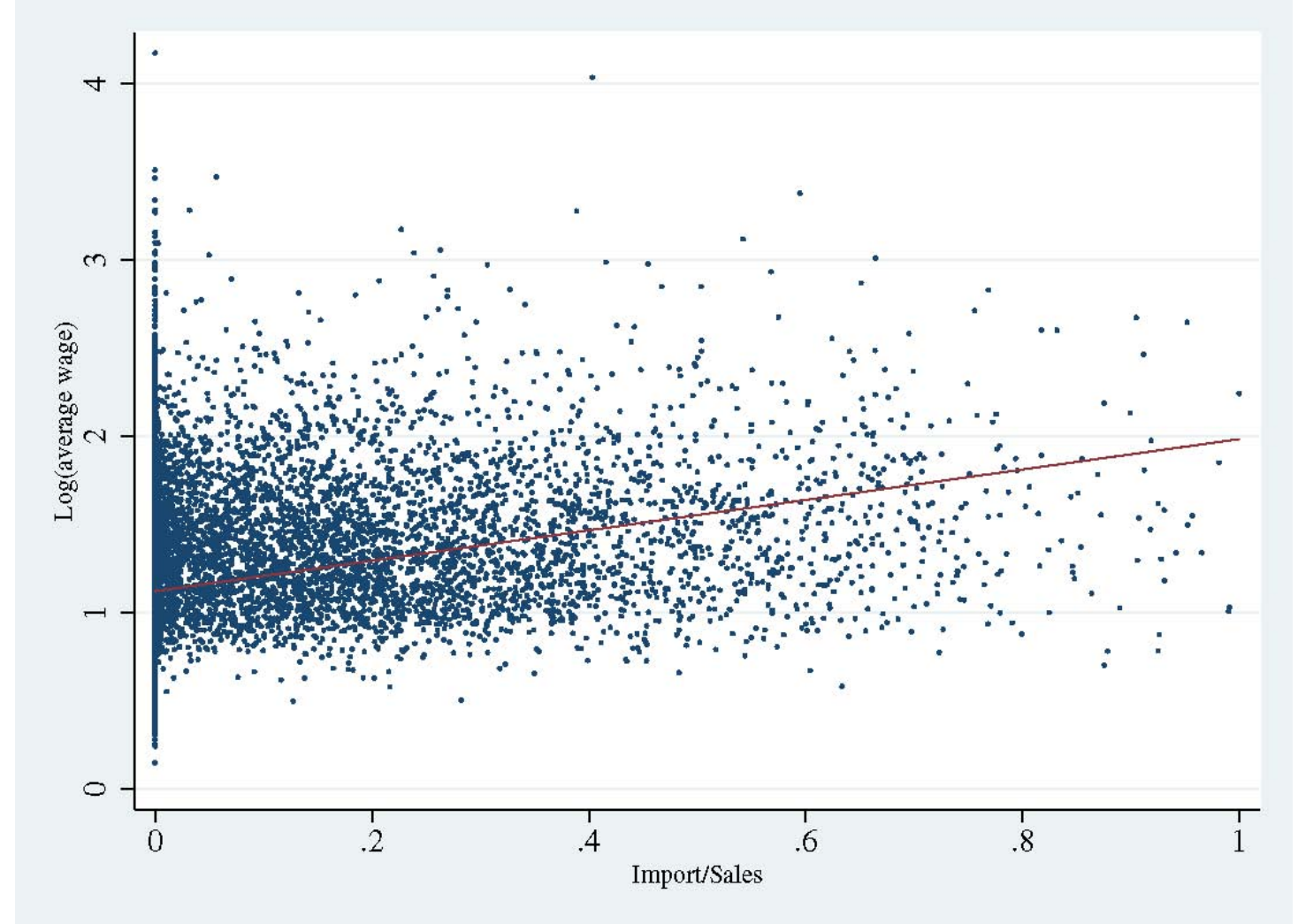

Note: Source: Authors calculations based on Quadros de Pessoal and INE trade data. Representative 10\% sample of all 1995-2005 pooled firm-level data. 
Figure 3: $\mathbf{X}$ and $\mathbf{M}$ shares in terms of sales

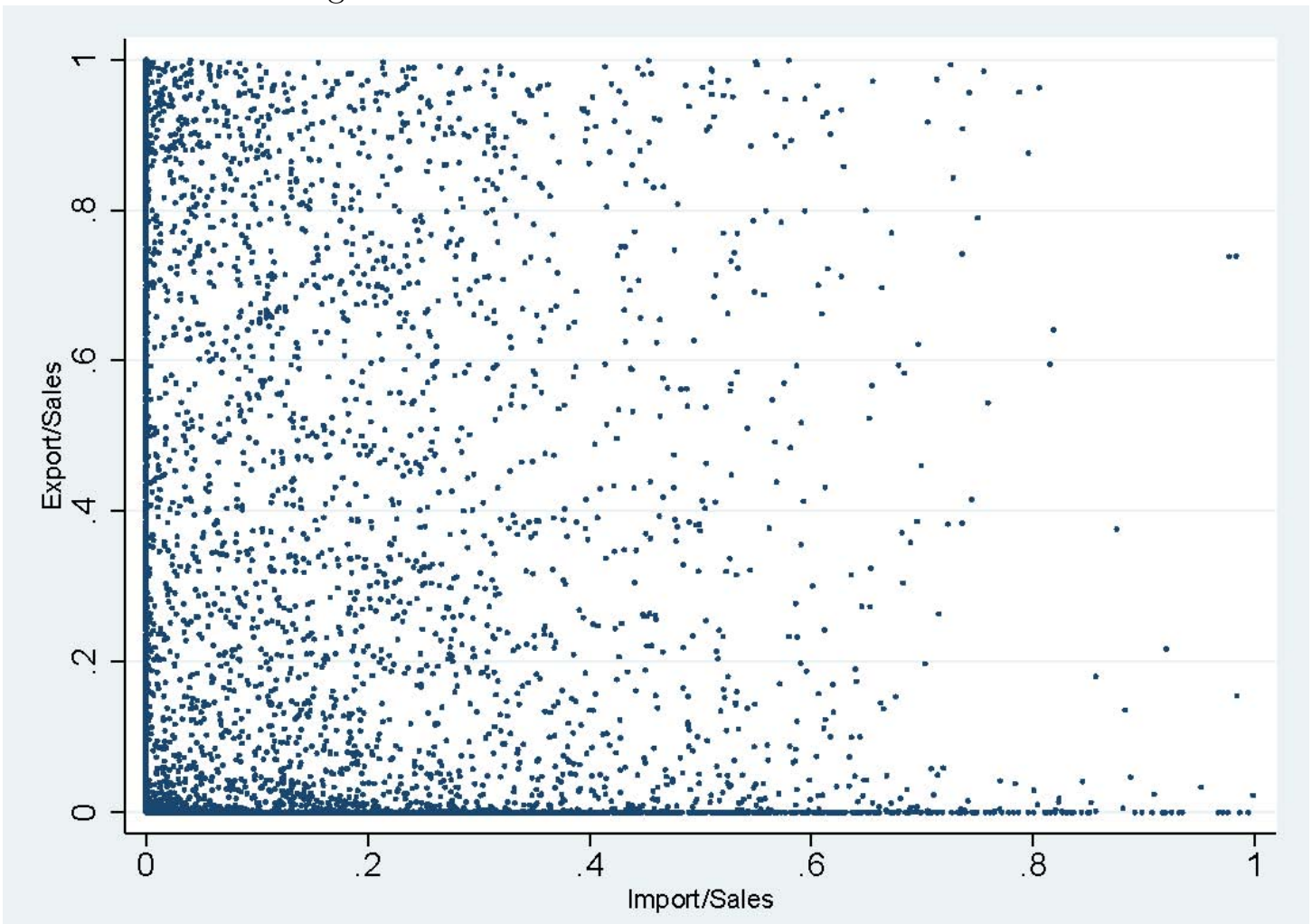

Note: Source: Authors calculations based on Quadros de Pessoal and INE trade data. Representative $10 \%$ sample of all 1995-2005 pooled firm-level data. 
Figure 4: Changes in $\mathbf{X}$ and $\mathbf{M}$ shares in terms of sales

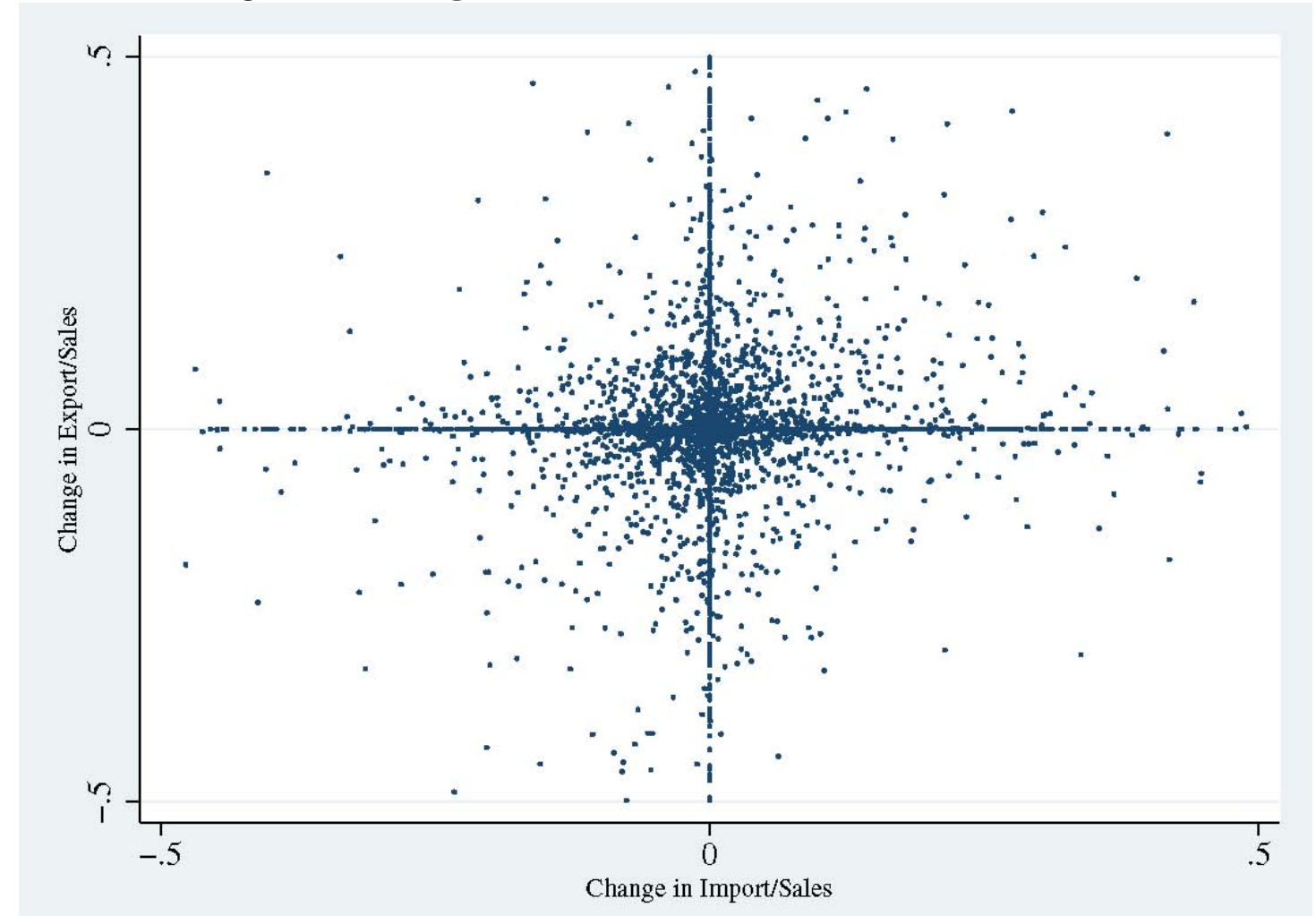

Note: Source: Authors calculations based on Quadros de Pessoal and INE trade data. Representative $10 \%$ sample of all 1995-2005 pooled firm-level data. 
Figure 5: Export shares by product type and wages
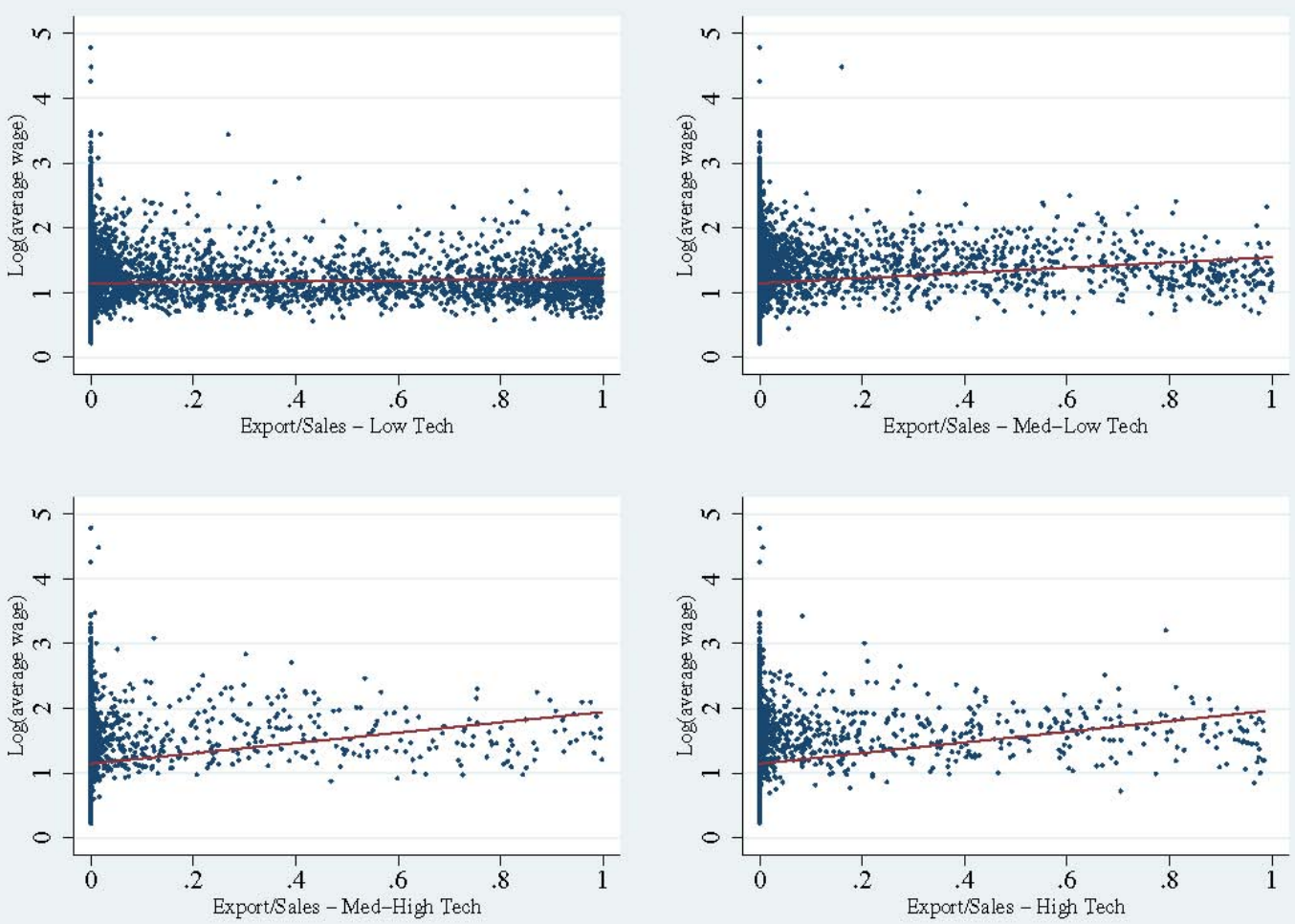

Note: Source: Authors calculations based on Quadros de Pessoal and INE trade data. Representative $10 \%$ sample of all 1995-2005 pooled firm-level data. 
Figure 6: Import shares by product type and wages
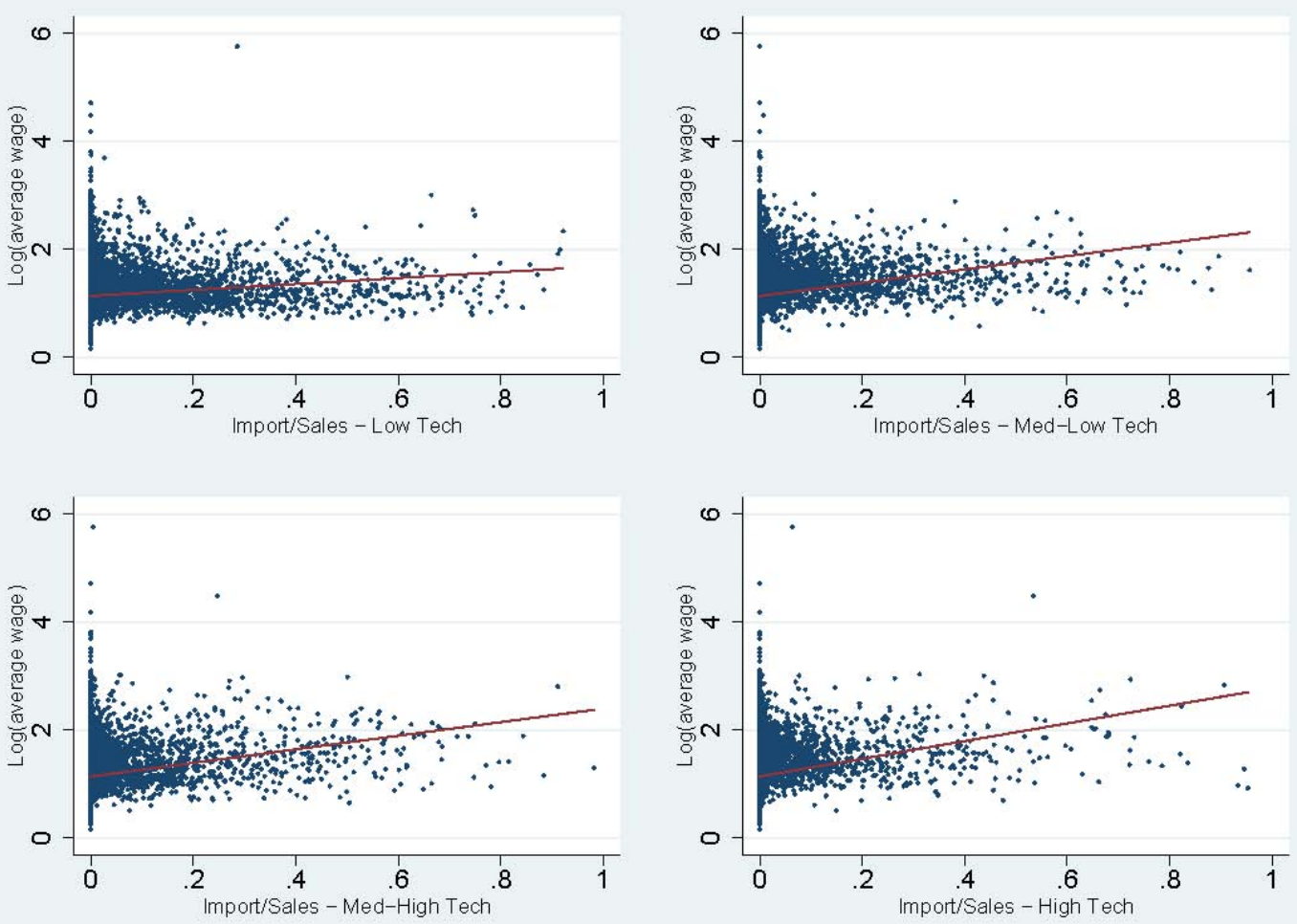

Note: Source: Authors calculations based on Quadros de Pessoal and INE trade data. Representative $10 \%$ sample of all 1995-2005 pooled firm-level data. 
Tables 


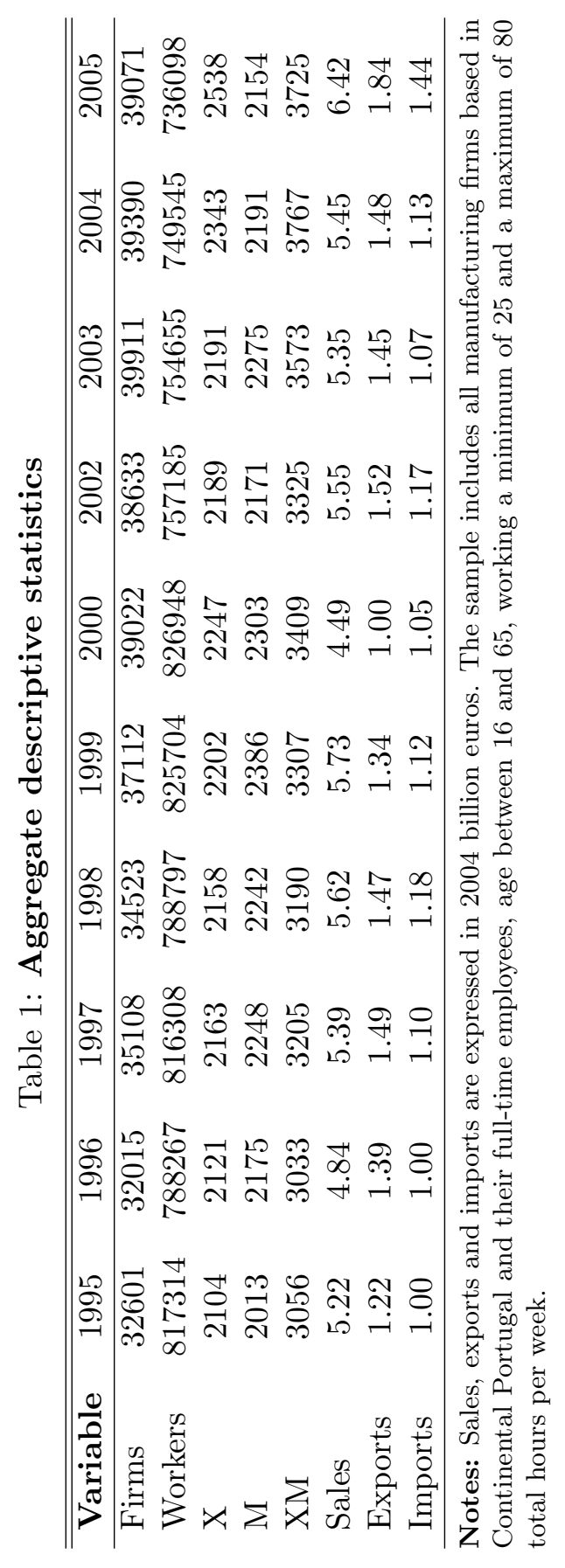


Table 2: Firm-level Descriptive statistics, pooled 1995-2005

\begin{tabular}{|c|c|c|c|c|}
\hline \multicolumn{5}{|c|}{$\begin{array}{c}\text { mean median stand } \\
\text { Non-Trading Firms }\end{array}$} \\
\hline Sales & 380.14 & 144.64 & 261.90 & 240843 \\
\hline Workers & 9.51 & 5.00 & 17.83 & 289382 \\
\hline Schooling & 6.10 & 6.00 & 2.10 & 285947 \\
\hline Experience & 22.51 & 21.71 & 9.09 & 285928 \\
\hline Tenure & 5.31 & 4.00 & 5.22 & 286377 \\
\hline Female & 0.36 & 0.20 & 0.39 & 289382 \\
\hline Hourly Wage & 3.12 & 2.78 & 1.49 & 289382 \\
\hline \multicolumn{5}{|c|}{ Exporters-only } \\
\hline Sales & 1271.05 & 639.03 & 5076.36 & 18381 \\
\hline Workers & 25.13 & 17.00 & 30.20 & 22256 \\
\hline Schooling & 6.28 & 5.96 & 1.95 & 22136 \\
\hline Experience & 23.51 & 23.05 & 7.40 & 22136 \\
\hline Tenure & 6.82 & 5.47 & 5.52 & 22145 \\
\hline Female & 0.47 & 0.46 & 0.33 & 22256 \\
\hline Hourly Wage & 3.61 & 3.21 & 1.98 & 22256 \\
\hline $\mathrm{X} / \mathrm{S}$ & 0.30 & 0.13 & 0.34 & 18381 \\
\hline \multicolumn{5}{|c|}{ Importers-only } \\
\hline Sales & 3209.56 & 1222.17 & 1070 & 19646 \\
\hline Workers & 33.84 & 19.00 & 59.08 & 22158 \\
\hline Schooling & 7.12 & 6.55 & 2.35 & 22006 \\
\hline Experience & 22.81 & 22.55 & 6.93 & 22006 \\
\hline Tenure & 7.08 & 5.83 & 5.40 & 22076 \\
\hline Female & 0.37 & 0.29 & 0.31 & 22158 \\
\hline Hourly Wage & 4.43 & 3.77 & 3.45 & 22158 \\
\hline $\mathrm{M} / \mathrm{S}$ & 0.24 & 0.16 & 0.37 & 19600 \\
\hline \multicolumn{5}{|c|}{ Exporters-Importers } \\
\hline Sales & 12700 & 3439.52 & 7730 & 28517 \\
\hline Workers & 113.11 & 56.00 & 228.76 & 33590 \\
\hline Schooling & 6.94 & 6.52 & 1.91 & 33459 \\
\hline Experience & 23.37 & 23.18 & 5.97 & 33459 \\
\hline Tenure & 8.75 & 7.60 & 5.61 & 33534 \\
\hline Female & 0.44 & 0.42 & 0.29 & 33590 \\
\hline Hourly Wage & 4.67 & 4.03 & 3.03 & 33590 \\
\hline $\mathrm{X} / \mathrm{S}$ & 0.37 & 0.28 & 0.34 & 28517 \\
\hline $\mathrm{M} / \mathrm{S}$ & 0.22 & 0.16 & 0.30 & 28499 \\
\hline
\end{tabular}

Notes: See the data appendix for variable definitions. 
Table 3: Worker-level Descriptive statistics, pooled 1995-2005

\begin{tabular}{|c|c|c|c|c|}
\hline & mean & median & standard dev. & $\mathrm{N}$ \\
\hline \multicolumn{5}{|c|}{ Non-Trading Firms } \\
\hline Sales & 2191.92 & 431.75 & 1060 & 1677921 \\
\hline Workers & 44.64 & 17.00 & 125.94 & 1959654 \\
\hline Schooling & 6.04 & 6.00 & 2.75 & 1929763 \\
\hline Experience & 23.21 & 21.00 & 12.23 & 1929255 \\
\hline Tenure & 6.62 & 4.00 & 7.48 & 1934240 \\
\hline Female & 0.42 & 0.00 & 0.49 & 1959654 \\
\hline Hourly Wage & 3.47 & 2.83 & 2.99 & 1959654 \\
\hline \multicolumn{5}{|c|}{ Exporters-only } \\
\hline Sales & 3045.95 & 1370.30 & 1270 & 342731 \\
\hline Workers & 61.49 & 39.00 & 72.09 & 419440 \\
\hline Schooling & 5.97 & 6.00 & 2.86 & 414429 \\
\hline Experience & 23.93 & 22.00 & 12.26 & 414317 \\
\hline Tenure & 8.14 & 6.00 & 8.33 & 415298 \\
\hline Female & 0.51 & 1.00 & 0.50 & 419440 \\
\hline Hourly Wage & 3.66 & 2.95 & 3.63 & 419440 \\
\hline $\mathrm{X} / \mathrm{S}$ & 0.34 & 0.17 & 0.36 & 342731 \\
\hline \multicolumn{5}{|c|}{ Importers-only } \\
\hline Sales & 13300 & 3335.86 & 3440 & 537925 \\
\hline Workers & 140.21 & 61.00 & 281.90 & 593651 \\
\hline Schooling & 6.89 & 6.00 & 3.54 & 586134 \\
\hline Experience & 23.94 & 23.00 & 12.27 & 585986 \\
\hline Tenure & 8.98 & 6.00 & 8.83 & 589432 \\
\hline Female & 0.37 & 0.00 & 0.48 & 593651 \\
\hline Hourly Wage & 5.01 & 3.63 & 9.15 & 593651 \\
\hline $\mathrm{M} / \mathrm{S}$ & 0.19 & 0.11 & 0.31 & 536211 \\
\hline \multicolumn{5}{|c|}{ Exporters-Importers } \\
\hline Sales & 87200 & 14400 & 37300 & 2528473 \\
\hline Workers & 552.53 & 228.00 & 943.04 & 3023376 \\
\hline Schooling & 6.96 & 6.00 & 3.55 & 3000042 \\
\hline Experience & 24.05 & 23.00 & 12.23 & 2999474 \\
\hline Tenure & 10.92 & 8.00 & 9.78 & 3012270 \\
\hline Female & 0.45 & 0.00 & 0.50 & 3023376 \\
\hline Hourly Wage & 5.26 & 3.88 & 8.16 & 3023376 \\
\hline $\mathrm{X} / \mathrm{S}$ & 0.44 & 0.40 & 0.34 & 2528473 \\
\hline $\mathrm{M} / \mathrm{S}$ & 0.24 & 0.19 & 0.26 & 2526684 \\
\hline
\end{tabular}

Notes: See the data appendix for variable definitions. 
Table 4: Trade Status Transition Matrix, Firms, Average 1995-2005

\begin{tabular}{|c|c|c|c|c|c|c|}
\hline \multirow{3}{*}{$\begin{array}{l}\text { Year } t-1 \\
\text { Non-Trader }\end{array}$} & \multicolumn{5}{|c|}{ Year $t$} & \multirow{3}{*}{$\begin{array}{c}\text { Total } \\
100 \\
(227,665)\end{array}$} \\
\hline & Non-Trader & Exporter Only & Importer Only & Exporter-Importer & Out & \\
\hline & $\begin{array}{c}77.74 \\
(176,993)\end{array}$ & $\begin{array}{c}1.77 \\
(4,021)\end{array}$ & $\begin{array}{c}1.03 \\
(2,348)\end{array}$ & $\begin{array}{l}0.21 \\
(486)\end{array}$ & $\begin{array}{c}19.25 \\
(43,817)\end{array}$ & \\
\hline Exporter Only & $\begin{array}{l}19.49 \\
(3,405)\end{array}$ & $\begin{array}{c}57.31 \\
(10,013)\end{array}$ & $\begin{array}{l}1.13 \\
(198)\end{array}$ & $\begin{array}{c}8.4 \\
(1,467)\end{array}$ & $\begin{array}{l}13.67 \\
(2,388)\end{array}$ & $\begin{array}{c}100 \\
(17,471)\end{array}$ \\
\hline Importer Only & $\begin{array}{l}12.29 \\
(2,176)\end{array}$ & $\begin{array}{l}1.03 \\
(182)\end{array}$ & $\begin{array}{c}65.73 \\
(11,634)\end{array}$ & $\begin{array}{c}9.78 \\
(1,731)\end{array}$ & $\begin{array}{l}11.17 \\
(1,978)\end{array}$ & $\begin{array}{c}100 \\
(17,701)\end{array}$ \\
\hline Exporter-Importer & $\begin{array}{l}1.46 \\
(385)\end{array}$ & $\begin{array}{c}4.85 \\
(1,282)\end{array}$ & $\begin{array}{c}5.64 \\
(1,492)\end{array}$ & $\begin{array}{c}79.48 \\
(21,027)\end{array}$ & $\begin{array}{l}8.58 \\
(2,270)\end{array}$ & $\begin{array}{c}100 \\
(26,456)\end{array}$ \\
\hline Out & $\begin{array}{c}87.32 \\
(50,047)\end{array}$ & $\begin{array}{c}4.3 \\
(2,465)\end{array}$ & $\begin{array}{c}4.02 \\
(2,302)\end{array}$ & $\begin{array}{c}4.36 \\
(2,498)\end{array}$ & $\begin{array}{c}0 \\
(0)\end{array}$ & $\begin{array}{c}100 \\
(57,312)\end{array}$ \\
\hline
\end{tabular}


Table 5: Trade Status Transition Matrix, Workers, Average 1995-2005

All workers

\begin{tabular}{l|ccccc|c}
\hline \hline & \multicolumn{5}{|c|}{ Year $t$} & \\
Year $t-1$ & Domestic & Exporter Only & Importer Only & Exporter-Importer & Out & Total \\
Domestic & 55.92 & 2.48 & 2.17 & 1.56 & 37.86 & 100 \\
& $(871,629)$ & $(38,697)$ & $(33,760)$ & $(24,357)$ & $(590,149)$ & $(1,558,592)$ \\
Exporter Only & 10.8 & 41.3 & 1.30 & 10.60 & 36.04 & 100 \\
& $(36,662)$ & $(140,113)$ & $(4,402)$ & $(35,979)$ & $(122,384)$ & $(339,540)$ \\
Importer Only & 6.96 & 0.82 & 48.89 & 11.18 & 32.16 & 100 \\
& $(33,469)$ & $(3,926)$ & $(235,198)$ & $(53,782)$ & $(154,713)$ & $(481,088)$ \\
Exporter-Importer & 0.87 & 1.43 & 2.07 & 65.34 & 30.29 & 100 \\
Out & $(21,325)$ & $(35,022)$ & $(50,506)$ & $(1,596,507)$ & $(740,069)$ & $(2,443,429)$ \\
& 37.92 & 7.33 & 9.59 & 45.16 & 0 & 100 \\
& $(602,125)$ & $(116,450)$ & $(152,280)$ & $(717,214)$ & $(0)$ & $(1,588,069)$ \\
\hline
\end{tabular}

Only workers staying in the same firm

\begin{tabular}{l|cccc|c}
\hline \hline & & & Year $t$ & & \\
Year $t-1$ & Domestic & Exporter Only & Importer Only & Exporter-Importer & Total \\
Domestic & 91.39 & 3.91 & 3.34 & 1.36 & 100 \\
& $(848,874)$ & $(36,356)$ & $(31,029)$ & $(12,635)$ & $(928,894)$ \\
Exporter Only & 16.17 & 66.06 & 1.91 & 15.86 & 100 \\
& $(33,902)$ & $(138,536)$ & $(4.002)$ & $(33,266)$ & $(209,706)$ \\
Importer Only & 9.69 & 1.12 & 73.41 & 15.78 & 100 \\
Exporter-Importer & $(30,839)$ & $(3,572)$ & $(233,507)$ & $(50,183)$ & $(318,101)$ \\
& 0.83 & 1.97 & 2.80 & 94.40 & 100 \\
& $(13,762)$ & $(32,730)$ & $(46,520)$ & $(1,567,523)$ & $(1,660,535)$ \\
\hline \hline
\end{tabular}


Table 6: Firms' Trade Status Paths, 2002-05

\begin{tabular}{ccccc}
\hline \hline Panel A & & & & \\
2002 & 2003 & 2004 & 2005 & Number of Firms \\
\hline NT & NT & NT & NT & 15698 \\
XM & XM & XM & XM & 1999 \\
M & M & M & M & 744 \\
X & X & X & X & 602 \\
NT & NT & NT & X & 289 \\
X & NT & NT & NT & 217 \\
NT & NT & X & X & 209 \\
NT & X & NT & NT & 183 \\
NT & NT & X & NT & 175 \\
M & M & NT & NT & 110 \\
\multicolumn{7}{c}{ (Others...) } \\
\hline \hline
\end{tabular}

\begin{tabular}{ccccc}
\hline \hline Panel B & & & & \\
2002 & 2003 & 2004 & 2005 & Avg. Number of Workers \\
\hline XM & XM & XM & XM & 188459.5 \\
NT & NT & NT & NT & 104127 \\
M & M & M & M & 18748.5 \\
X & X & X & X & 9207 \\
M & XM & XM & XM & 3712.5 \\
M & M & XM & XM & 3162.5 \\
NT & NT & NT & X & 2938.3 \\
M & M & M & XM & 2682.8 \\
NT & NT & X & X & 2366.5 \\
X & NT & NT & NT & 2160.8 \\
& (Others...) & & 59724 \\
\hline \hline
\end{tabular}

Notes: Actual paths, by trade status, for all firms that are active throughout the 2002-2005 period. NT stands for "non-trader", X stands for "exporter only", M stands for "importer only" and XM stands for "exporter-importer". The column "Avg. Number of Workers" shows the total number of workers employed, on average, by the firms following each path. 
Table 7: Firm-level analysis - Discrete X status

\begin{tabular}{|c|c|c|c|c|}
\hline & $(1)$ & $(2)$ & $(3)$ & $(4)$ \\
\hline Exporter & $\begin{array}{c}.255 \\
(.004)^{* * *}\end{array}$ & $\begin{array}{c}.191 \\
(.003)^{* * *}\end{array}$ & $\begin{array}{c}.057 \\
(.003)^{* * *}\end{array}$ & $\begin{array}{c}.007 \\
(.002)^{* * *}\end{array}$ \\
\hline Schooling & & $\begin{array}{c}.066 \\
(.0007)^{* * *}\end{array}$ & $\begin{array}{c}.070 \\
(.0008)^{* * *}\end{array}$ & $\begin{array}{c}.029 \\
(.0009)^{* * *}\end{array}$ \\
\hline Experience & & $\begin{array}{c}.033 \\
(.0004)^{* * *}\end{array}$ & $\begin{array}{c}.025 \\
(.0005)^{* * *}\end{array}$ & $\begin{array}{l}.017 \\
(.0006)^{* * *}\end{array}$ \\
\hline$\left(\right.$ Experience $\left.^{2}\right) / 100$ & & $\begin{array}{c}-.048 \\
(.0008)^{* * *}\end{array}$ & $\begin{array}{l}-.029 \\
(.001)^{* * *}\end{array}$ & $\begin{array}{l}-.019 \\
(.001)^{* * *}\end{array}$ \\
\hline Tenure & & $\begin{array}{c}.008 \\
(.0004)^{* * *}\end{array}$ & $\begin{array}{c}.003 \\
(.0005)^{* * *}\end{array}$ & $\begin{array}{c}.005 \\
(.0006)^{* * *}\end{array}$ \\
\hline$\left(\right.$ Tenure $\left.^{2}\right) / 100$ & & $\begin{array}{l}-.009 \\
(.002)^{* * *}\end{array}$ & $\begin{array}{l}.0005 \\
(.002)\end{array}$ & $\begin{array}{l}-.010 \\
(.002)^{* * *}\end{array}$ \\
\hline Female share & & $\begin{array}{l}-.185 \\
(.002)^{* * *}\end{array}$ & $\begin{array}{l}-.260 \\
(.003)^{* * *}\end{array}$ & $\begin{array}{l}-.156 \\
(.005)^{* * *}\end{array}$ \\
\hline Log hours & & $\begin{array}{l}-.634 \\
(.019)^{* * *}\end{array}$ & $\begin{array}{l}-.714 \\
(.022)^{* * *}\end{array}$ & $\begin{array}{l}-.741 \\
(.015)^{* * *}\end{array}$ \\
\hline Log firm size & & & $\begin{array}{l}.072 \\
(.001)^{* * *}\end{array}$ & $\begin{array}{l}.012 \\
(.003)^{* * *}\end{array}$ \\
\hline No. establishments & & & $\begin{array}{c}-.0001 \\
(.0009)\end{array}$ & $\begin{array}{l}.003 \\
(.001)^{* *}\end{array}$ \\
\hline Foreign & & & $\begin{array}{c}.275 \\
(.010)^{* * *}\end{array}$ & $\begin{array}{l}.040 \\
(.011)^{* * *}\end{array}$ \\
\hline Worker controls & & $\mathrm{x}$ & $\mathrm{x}$ & $\mathrm{x}$ \\
\hline Firm controls & & & $\mathrm{x}$ & $\mathrm{x}$ \\
\hline Firm fixed effects & & & & $\mathrm{x}$ \\
\hline Obs. & 367386 & 360449 & 258190 & 258190 \\
\hline$R^{2}$ & .116 & .388 & .447 & .833 \\
\hline
\end{tabular}

Notes: Source: Author's calculations based on Quadros de Pessoal and INE trade data. Robust standard errors, allowing for clustering at the firm level. Significance levels: ${ }^{* *} 1 \%$; ${ }^{*} 5 \%$; ${ }^{*} 10 \%$. 
Table 8: Firm-level analysis - Discrete X, M and XM status

\begin{tabular}{|c|c|c|c|c|}
\hline & (1) & $(2)$ & $(3)$ & (4) \\
\hline Exporter only & $\begin{array}{c}.140 \\
(.004)^{* * *}\end{array}$ & $\begin{array}{c}.113 \\
(.003)^{* * *}\end{array}$ & $\begin{array}{c}.048 \\
(.003)^{* * *}\end{array}$ & $\begin{array}{c}.009 \\
(.003)^{* * *}\end{array}$ \\
\hline Importer only & $\begin{array}{c}.312 \\
(.005)^{* * *}\end{array}$ & $\begin{array}{c}.214 \\
(.004)^{* * *}\end{array}$ & $\begin{array}{c}.118 \\
(.004)^{* * *}\end{array}$ & $\begin{array}{c}.017 \\
(.003)^{* * *}\end{array}$ \\
\hline Exporter-Importer & $\begin{array}{c}.368 \\
(.005)^{* * *}\end{array}$ & $\begin{array}{c}.286 \\
(.004)^{* * *}\end{array}$ & $\begin{array}{c}.114 \\
(.004)^{* * *}\end{array}$ & $\begin{array}{c}.019 \\
(.003)^{* * *}\end{array}$ \\
\hline Schooling & & $\begin{array}{c}.060 \\
(.0007)^{* * *}\end{array}$ & $\begin{array}{c}.066 \\
(.0008)^{* * *}\end{array}$ & $\begin{array}{c}.029 \\
(.0009)^{* * *}\end{array}$ \\
\hline Experience & & $\begin{array}{c}.030 \\
(.0004)^{* * *}\end{array}$ & $\begin{array}{c}.024 \\
(.0005)^{* * *}\end{array}$ & $\begin{array}{c}.017 \\
(.0006)^{* * *}\end{array}$ \\
\hline$\left(\right.$ Experience $\left.^{2}\right) / 100$ & & $\begin{array}{c}-.043 \\
(.0008)^{* * *}\end{array}$ & $\begin{array}{c}-.029 \\
(.001)^{* * *}\end{array}$ & $\begin{array}{c}-.019 \\
(.001)^{* * *}\end{array}$ \\
\hline Tenure & & $\begin{array}{c}.006 \\
(.0004)^{* * *}\end{array}$ & $\begin{array}{c}.003 \\
(.0005)^{* * *}\end{array}$ & $\begin{array}{c}.005 \\
(.0006)^{* * *}\end{array}$ \\
\hline$\left(\right.$ Tenure $\left.^{2}\right) / 100$ & & $\begin{array}{l}-.003 \\
(.002)^{*}\end{array}$ & $\begin{array}{l}.002 \\
(.002)\end{array}$ & $\begin{array}{c}-.010 \\
(.002)^{* * *}\end{array}$ \\
\hline Female share & & $\begin{array}{c}-.185 \\
(.002)^{* * *}\end{array}$ & $\begin{array}{c}-.257 \\
(.003)^{* * *}\end{array}$ & $\begin{array}{c}-.156 \\
(.005)^{* * *}\end{array}$ \\
\hline Log hours & & $\begin{array}{c}-.665 \\
(.018)^{* * *}\end{array}$ & $\begin{array}{c}-.720 \\
(.022)^{* * *}\end{array}$ & $\begin{array}{c}-.741 \\
(.015)^{* * *}\end{array}$ \\
\hline Log firm size & & & $\begin{array}{c}.061 \\
(.001)^{* * *}\end{array}$ & $\begin{array}{c}.011 \\
(.003)^{* * *}\end{array}$ \\
\hline No. establishments & & & $\begin{array}{l}.0005 \\
(.0008)\end{array}$ & $\begin{array}{c}.003 \\
(.001)^{* *}\end{array}$ \\
\hline Foreign & & & $\begin{array}{c}.257 \\
(.010)^{* * *}\end{array}$ & $\begin{array}{c}.040 \\
(.011)^{* * *}\end{array}$ \\
\hline Worker controls & & $\mathrm{x}$ & $\mathrm{x}$ & $\mathrm{x}$ \\
\hline Firm controls & & & $\mathrm{x}$ & $\mathrm{x}$ \\
\hline Firm fixed effects & & & & $\mathrm{x}$ \\
\hline Obs. & 367386 & 360449 & 258190 & 258190 \\
\hline$R^{2}$ & .176 & .416 & .455 & .833 \\
\hline
\end{tabular}

Notes: Source: Author's calculations based on Quadros de Pessoal and INE trade data. Robust standard errors, allowing for clustering at the firm level. Significance levels: *** $1 \%$; ** $5 \%$; * $10 \%$. 
Table 9: Firm-level analysis - $\mathbf{X}$ as percentage of sales

\begin{tabular}{|c|c|c|c|c|}
\hline & $(1)$ & $(2)$ & (3) & (4) \\
\hline $\mathrm{X} / \mathrm{S}$ & $\begin{array}{c}.268 \\
(.008)^{* * *}\end{array}$ & $\begin{array}{c}.246 \\
(.005)^{* * *}\end{array}$ & $\begin{array}{c}.031 \\
(.005)^{* * *}\end{array}$ & $\begin{array}{l}.013 \\
(.007)^{*}\end{array}$ \\
\hline Schooling & & $\begin{array}{c}.070 \\
(.0008)^{* * *}\end{array}$ & $\begin{array}{c}.070 \\
(.0008)^{* * *}\end{array}$ & $\begin{array}{c}.028 \\
(.0009)^{* * *}\end{array}$ \\
\hline Experience & & $\begin{array}{c}.036 \\
(.0005)^{* * *}\end{array}$ & $\begin{array}{c}.025 \\
(.0006)^{* * *}\end{array}$ & $\begin{array}{c}.017 \\
(.0006)^{* * *}\end{array}$ \\
\hline$\left(\right.$ Experience $\left.^{2}\right) / 100$ & & $\begin{array}{c}-.054 \\
(.0009)^{* * *}\end{array}$ & $\begin{array}{l}-.029 \\
(.001)^{* * *}\end{array}$ & $\begin{array}{l}-.019 \\
(.001)^{* * *}\end{array}$ \\
\hline Tenure & & $\begin{array}{c}.011 \\
(.0004)^{* * *}\end{array}$ & $\begin{array}{c}.004 \\
(.0005)^{* * *}\end{array}$ & $\begin{array}{c}.006 \\
(.0006)^{* * *}\end{array}$ \\
\hline$\left(\right.$ Tenure $\left.^{2}\right) / 100$ & & $\begin{array}{l}-.014 \\
(.002)^{* * *}\end{array}$ & $\begin{array}{r}-.001 \\
(.002)\end{array}$ & $\begin{array}{l}-.011 \\
(.002)^{* * *}\end{array}$ \\
\hline Female share & & $\begin{array}{l}-.185 \\
(.002)^{* * *}\end{array}$ & $\begin{array}{l}-.261 \\
(.003)^{* * *}\end{array}$ & $\begin{array}{l}-.152 \\
(.006)^{* * * *}\end{array}$ \\
\hline Log hours & & $\begin{array}{l}-.623 \\
(.021)^{* * *}\end{array}$ & $\begin{array}{c}-.713 \\
(.023)^{* * *}\end{array}$ & $\begin{array}{c}-.748 \\
(.016)^{* * *}\end{array}$ \\
\hline Log firm size & & & $\begin{array}{l}.082 \\
(.001)^{* * *}\end{array}$ & $\begin{array}{l}.020 \\
(.003)^{* * *}\end{array}$ \\
\hline No. establishments & & & $\begin{array}{l}-.001 \\
(.0009)\end{array}$ & $\begin{array}{c}.003 \\
(.001)^{* *}\end{array}$ \\
\hline Foreign & & & $\begin{array}{c}.281 \\
(.011)^{* * *}\end{array}$ & $\begin{array}{l}.037 \\
(.011)^{* * *}\end{array}$ \\
\hline Worker controls & & $\mathrm{x}$ & $\mathrm{x}$ & $\mathrm{x}$ \\
\hline Firm controls & & & $\mathrm{x}$ & $\mathrm{x}$ \\
\hline Firm fixed effects & & & & $\mathrm{x}$ \\
\hline Obs. & 307387 & 302101 & 222869 & 222869 \\
\hline$R^{2}$ & .069 & .374 & .451 & .84 \\
\hline
\end{tabular}

Notes: Source: Author's calculations based on Quadros de Pessoal and INE trade data. Robust standard errors, allowing for clustering at the firm level. Significance levels: ${ }^{* *} 1 \%$; ${ }^{*} 5 \%$; ${ }^{*} 10 \%$. 
Table 10: Firm-level analysis - $\mathbf{X}$ and $\mathbf{M}$ as percentage of sales

\begin{tabular}{|c|c|c|c|c|}
\hline & $(1)$ & $(2)$ & $(3)$ & $(4)$ \\
\hline $\mathrm{X} / \mathrm{S}$ & $\begin{array}{l}.198 \\
(.008)^{* * *}\end{array}$ & $\begin{array}{c}.205 \\
(.006)^{* * *}\end{array}$ & $\begin{array}{c}.023 \\
(.006)^{* * *}\end{array}$ & $\begin{array}{c}.012 \\
(.007)^{*}\end{array}$ \\
\hline $\mathrm{M} / \mathrm{S}$ & $\begin{array}{c}.436 \\
(.026)^{* * *}\end{array}$ & $\begin{array}{c}.284 \\
(.018)^{* * *}\end{array}$ & $\begin{array}{c}.129 \\
(.010)^{* * * *}\end{array}$ & $\begin{array}{l}.003 \\
(.005)\end{array}$ \\
\hline Schooling & & $\begin{array}{c}.067 \\
(.0008)^{* * *}\end{array}$ & $\begin{array}{c}.068 \\
(.0008)^{* * *}\end{array}$ & $\begin{array}{c}.028 \\
(.0009)^{* * *}\end{array}$ \\
\hline Experience & & $\begin{array}{c}.035 \\
(.0005)^{* * *}\end{array}$ & $\begin{array}{c}.024 \\
(.0006)^{* * *}\end{array}$ & $\begin{array}{c}.017 \\
(.0006)^{* * * *}\end{array}$ \\
\hline$\left(\right.$ Experience $\left.^{2}\right) / 100$ & & $\begin{array}{c}-.051 \\
(.0009)^{* * *}\end{array}$ & $\begin{array}{l}-.029 \\
(.001)^{* * *}\end{array}$ & $\begin{array}{c}-.019 \\
(.001)^{* * *}\end{array}$ \\
\hline Tenure & & $\begin{array}{c}.010 \\
(.0004)^{* * *}\end{array}$ & $\begin{array}{c}.004 \\
(.0005)^{* * *}\end{array}$ & $\begin{array}{c}.006 \\
(.0006)^{* * *}\end{array}$ \\
\hline$\left(\right.$ Tenure $\left.^{2}\right) / 100$ & & $\begin{array}{l}-.012 \\
(.002)^{* * *}\end{array}$ & $\begin{array}{c}-.0009 \\
(.002)\end{array}$ & $\begin{array}{l}-.011 \\
(.002)^{* * *}\end{array}$ \\
\hline Female share & & $\begin{array}{l}-.185 \\
(.002)^{* * *}\end{array}$ & $\begin{array}{l}-.260 \\
(.003)^{* * *}\end{array}$ & $\begin{array}{l}-.152 \\
(.006)^{* * *}\end{array}$ \\
\hline Log hours & & $\begin{array}{l}-.640 \\
(.020)^{* * *}\end{array}$ & $\begin{array}{l}-.717 \\
(.023)^{* * *}\end{array}$ & $\begin{array}{l}-.747 \\
(.016)^{* * *}\end{array}$ \\
\hline Log firm size & & & $\begin{array}{l}.079 \\
(.001)^{* * *}\end{array}$ & $\begin{array}{c}.020 \\
(.003)^{* * *}\end{array}$ \\
\hline No. establishments & & & $\begin{array}{r}-.0007 \\
(.0009)\end{array}$ & $\begin{array}{c}.003 \\
(.001)^{* *}\end{array}$ \\
\hline Foreign & & & $\begin{array}{c}.255 \\
(.011)^{* * *}\end{array}$ & $\begin{array}{c}.039 \\
(.011)^{* * *}\end{array}$ \\
\hline Worker controls & & $\mathrm{x}$ & $\mathrm{x}$ & $\mathrm{x}$ \\
\hline Firm controls & & & $\mathrm{x}$ & $\mathrm{x}$ \\
\hline Firm fixed effects & & & & $\mathrm{x}$ \\
\hline Obs. & 307323 & 302039 & 222807 & 222807 \\
\hline$R^{2}$ & .105 & .389 & .454 & .84 \\
\hline
\end{tabular}

Notes: Source: Author's calculations based on Quadros de Pessoal and INE trade data. Robust standard errors, allowing for clustering at the firm level. Significance levels: *** $1 \%$; ** $5 \%$; ${ }^{*} 10 \%$. 
Table 11: Worker-level analysis - Discrete X status

\begin{tabular}{|c|c|c|c|c|c|c|c|}
\hline & $(1)$ & $(2)$ & $(3)$ & $(4)$ & $(5)$ & $(6)$ & $(7)$ \\
\hline Exporter & $\begin{array}{c}.234 \\
(.012)^{* * *}\end{array}$ & $\begin{array}{c}.151 \\
(.007)^{* * *}\end{array}$ & $\begin{array}{c}.023 \\
(.006)^{* * *}\end{array}$ & $\begin{array}{l}.002 \\
(.003)\end{array}$ & $\begin{array}{l}.003 \\
(.003)\end{array}$ & $\begin{array}{c}.005 \\
(.0004)^{* * *}\end{array}$ & $\begin{array}{l}.002 \\
(.003)\end{array}$ \\
\hline Schooling & & $\begin{array}{c}.095 \\
(.001)^{* * *}\end{array}$ & $\begin{array}{c}.078 \\
(.0007)^{* * *}\end{array}$ & $\begin{array}{c}.033 \\
(.0005)^{* * *}\end{array}$ & $\begin{array}{c}.069 \\
(.0006)^{* * *}\end{array}$ & $\begin{array}{c}.006 \\
(.0003)^{* * *}\end{array}$ & $\begin{array}{c}.031 \\
(.0007)^{* * *}\end{array}$ \\
\hline Experience & & $\begin{array}{c}.032 \\
(.0005)^{* * *}\end{array}$ & $\begin{array}{c}.030 \\
(.0003)^{* * *}\end{array}$ & $\begin{array}{c}.043 \\
(.0006)^{* * *}\end{array}$ & $\begin{array}{c}.028 \\
(.0002)^{* * *}\end{array}$ & $\begin{array}{c}.015 \\
(.0003)^{* * *}\end{array}$ & $\begin{array}{c}.041 \\
(.0009)^{* * *}\end{array}$ \\
\hline$\left(\right.$ Experience $\left.^{2}\right) / 100$ & & $\begin{array}{c}-.037 \\
(.0007)^{* * *}\end{array}$ & $\begin{array}{c}-.036 \\
(.0005)^{* * *}\end{array}$ & $\begin{array}{c}-.032 \\
(.001)^{* * *}\end{array}$ & $\begin{array}{c}-.033 \\
(.0004)^{* * *}\end{array}$ & $\begin{array}{c}-.030 \\
(.0002)^{* * *}\end{array}$ & $\begin{array}{c}-.027 \\
(.001)^{* * *}\end{array}$ \\
\hline Tenure & & $\begin{array}{c}.012 \\
(.0005)^{* * *}\end{array}$ & $\begin{array}{c}.011 \\
(.0004)^{* * *}\end{array}$ & $\begin{array}{c}.004 \\
(.0004)^{* * *}\end{array}$ & $\begin{array}{c}.011 \\
(.0003)^{* * *}\end{array}$ & $\begin{array}{c}.004 \\
(.00007)^{* * *}\end{array}$ & $\begin{array}{c}.003 \\
(.0006)^{* * *}\end{array}$ \\
\hline$\left(\right.$ Tenure $\left.^{2}\right) / 100$ & & $\begin{array}{c}-.017 \\
(.002)^{* * *}\end{array}$ & $\begin{array}{c}-.018 \\
(.001)^{* * *}\end{array}$ & $\begin{array}{c}-.013 \\
(.001)^{* * *}\end{array}$ & $\begin{array}{c}-.019 \\
(.0009)^{* * *}\end{array}$ & $\begin{array}{c}-.011 \\
(.0002)^{* * *}\end{array}$ & $\begin{array}{c}-.012 \\
(.002)^{* * *}\end{array}$ \\
\hline Female & & $\begin{array}{c}-.294 \\
(.005)^{* * *}\end{array}$ & $\begin{array}{c}-.262 \\
(.004)^{* * *}\end{array}$ & & $\begin{array}{c}-.234 \\
(.003)^{* * *}\end{array}$ & & \\
\hline Log hours & & $\begin{array}{c}-.203 \\
(.050)^{* * *}\end{array}$ & $\begin{array}{c}-.337 \\
(.030)^{* * *}\end{array}$ & $\begin{array}{c}-.180 \\
(.026)^{* * *}\end{array}$ & $\begin{array}{c}-.283 \\
(.023)^{* * *}\end{array}$ & $\begin{array}{c}-.164 \\
(.002)^{* * *}\end{array}$ & $\begin{array}{c}-.177 \\
(.028)^{* * *}\end{array}$ \\
\hline Log firm size & & & $\begin{array}{c}.056 \\
(.003)^{* * *}\end{array}$ & $\begin{array}{c}.043 \\
(.002)^{* * *}\end{array}$ & $\begin{array}{c}.025 \\
(.004)^{* * *}\end{array}$ & $\begin{array}{c}.073 \\
(.0004)^{* * *}\end{array}$ & $\begin{array}{c}.065 \\
(.006)^{* * *}\end{array}$ \\
\hline No. establishments & & & $\begin{array}{c}-.002 \\
(.0006)^{* * *}\end{array}$ & $\begin{array}{r}-.0002 \\
(.0005)\end{array}$ & $\begin{array}{c}.001 \\
(.0007)^{*}\end{array}$ & $\begin{array}{l}.00006 \\
(.00007)\end{array}$ & $\begin{array}{c}1.00 \mathrm{e}-05 \\
\quad(.0009)\end{array}$ \\
\hline Foreign & & & $\begin{array}{c}.081 \\
(.012)^{* * *}\end{array}$ & $\begin{array}{c}.034 \\
(.007)^{* * *}\end{array}$ & $\begin{array}{c}.019 \\
(.008)^{* *}\end{array}$ & $\begin{array}{c}.028 \\
(.0007)^{* * *}\end{array}$ & $\begin{array}{c}.015 \\
(.009)^{*}\end{array}$ \\
\hline Worker controls & & $\mathrm{x}$ & $\mathrm{x}$ & $\mathrm{x}$ & $\mathrm{x}$ & $\mathrm{x}$ & $\mathrm{x}$ \\
\hline Firm controls & & & $\mathrm{x}$ & $\mathrm{x}$ & $\mathrm{x}$ & $\mathrm{x}$ & $\mathrm{x}$ \\
\hline Worker fixed effects & & & & $\mathrm{x}$ & & $\mathrm{x}$ & \\
\hline Firm fixed effects & & & & & $\mathrm{x}$ & $\mathrm{x}$ & \\
\hline Spell fixed effects & & & & & & & $\mathrm{x}$ \\
\hline Obs. & 5996121 & 5886189 & 5521063 & 5521063 & 5521063 & 5521063 & 5521063 \\
\hline$R^{2}$ & .075 & .483 & .568 & .909 & .678 & .176 & .925 \\
\hline
\end{tabular}

Notes: Source: Author's calculations based on Quadros de Pessoal and INE trade data. Robust standard errors, allowing for clustering at the firm level (except in specification 4, which allow for clustering at the worker level). Significance levels: ${ }^{* *} 1 \%$; ${ }^{* *} 5 \%$; ${ }^{*} 10 \%$. 
Table 12: Worker-level analysis - Discrete $\mathbf{X}, \mathbf{M}$ and XM status

\begin{tabular}{|c|c|c|c|c|c|c|c|}
\hline & $(1)$ & $(2)$ & $(3)$ & (4) & $(5)$ & (6) & $(7)$ \\
\hline Exporter only & $\begin{array}{c}.054 \\
(.007)^{* * *}\end{array}$ & $\begin{array}{c}.059 \\
(.005)^{* * *}\end{array}$ & $\begin{array}{c}.018 \\
(.005)^{* * *}\end{array}$ & $\begin{array}{c}.006 \\
(.003)^{*}\end{array}$ & $\begin{array}{c}.007 \\
(.003)^{* *}\end{array}$ & $\begin{array}{c}.007 \\
(.0006)^{* * *}\end{array}$ & $\begin{array}{c}.006 \\
(.003)^{*}\end{array}$ \\
\hline Importer only & $\begin{array}{c}.278 \\
(.016)^{* * *}\end{array}$ & $\begin{array}{c}.151 \\
(.009)^{* * *}\end{array}$ & $\begin{array}{c}.068 \\
(.007)^{* * *}\end{array}$ & $\begin{array}{c}.011 \\
(.004)^{* * *}\end{array}$ & $\begin{array}{c}.012 \\
(.003)^{* * *}\end{array}$ & $\begin{array}{c}.010 \\
(.0006)^{* * *}\end{array}$ & $\begin{array}{c}.007 \\
(.004)^{*}\end{array}$ \\
\hline Exporter-Importer & $\begin{array}{c}.333 \\
(.013)^{* * *}\end{array}$ & $\begin{array}{c}.209 \\
(.007)^{* * *}\end{array}$ & $\begin{array}{c}.058 \\
(.007)^{* * *}\end{array}$ & $\begin{array}{c}.007 \\
(.004)^{*}\end{array}$ & $\begin{array}{c}.010 \\
(.004)^{* * *}\end{array}$ & $\begin{array}{c}.011 \\
(.0006)^{* * *}\end{array}$ & $\begin{array}{l}.006 \\
(.004)\end{array}$ \\
\hline Schooling & & $\begin{array}{c}.092 \\
(.001)^{* * *}\end{array}$ & $\begin{array}{c}.077 \\
(.0007)^{* * *}\end{array}$ & $\begin{array}{c}.033 \\
(.0005)^{* * *}\end{array}$ & $\begin{array}{c}.069 \\
(.0006)^{* * *}\end{array}$ & $\begin{array}{c}.006 \\
(.0003)^{* * *}\end{array}$ & $\begin{array}{c}.031 \\
(.0007)^{* * *}\end{array}$ \\
\hline Experience & & $\begin{array}{c}.032 \\
(.0005)^{* * *}\end{array}$ & $\begin{array}{c}.030 \\
(.0003)^{* * *}\end{array}$ & $\begin{array}{c}.043 \\
(.0006)^{* * *}\end{array}$ & $\begin{array}{c}.028 \\
(.0002)^{* * *}\end{array}$ & $\begin{array}{c}.015 \\
(.0003)^{* * *}\end{array}$ & $\begin{array}{c}.041 \\
(.0009)^{* * *}\end{array}$ \\
\hline$\left(\right.$ Experience $\left.^{2}\right) / 100$ & & $\begin{array}{c}-.036 \\
(.0007)^{* * *}\end{array}$ & $\begin{array}{c}-.036 \\
(.0005)^{* * *}\end{array}$ & $\begin{array}{c}-.032 \\
(.001)^{* * *}\end{array}$ & $\begin{array}{c}-.033 \\
(.0004)^{* * *}\end{array}$ & $\begin{array}{c}-.030 \\
(.0002)^{* * *}\end{array}$ & $\begin{array}{c}-.027 \\
(.001)^{* * *}\end{array}$ \\
\hline Tenure & & $\begin{array}{c}.011 \\
(.0005)^{* * *}\end{array}$ & $\begin{array}{c}.010 \\
(.0004)^{* * *}\end{array}$ & $\begin{array}{c}.004 \\
(.0004)^{* * *}\end{array}$ & $\begin{array}{c}.011 \\
(.0003)^{* * *}\end{array}$ & $\begin{array}{c}.004 \\
(.00007)^{* * *}\end{array}$ & $\begin{array}{c}.003 \\
(.0006)^{* * *}\end{array}$ \\
\hline$\left(\right.$ Tenure $\left.^{2}\right) / 100$ & & $\begin{array}{c}-.016 \\
(.002)^{* * *}\end{array}$ & $\begin{array}{c}-.018 \\
(.001)^{* * *}\end{array}$ & $\begin{array}{c}-.013 \\
(.001)^{* * *}\end{array}$ & $\begin{array}{c}-.019 \\
(.0009)^{* * *}\end{array}$ & $\begin{array}{c}-.011 \\
(.0002)^{* * *}\end{array}$ & $\begin{array}{c}-.012 \\
(.002)^{* * *}\end{array}$ \\
\hline Female & & $\begin{array}{c}-.291 \\
(.004)^{* * *}\end{array}$ & $\begin{array}{c}-.261 \\
(.004)^{* * *}\end{array}$ & & $\begin{array}{c}-.234 \\
(.003)^{* * *}\end{array}$ & & \\
\hline Log hours & & $\begin{array}{c}-.229 \\
(.048)^{* * *}\end{array}$ & $\begin{array}{c}-.335 \\
(.030)^{* * *}\end{array}$ & $\begin{array}{c}-.180 \\
(.026)^{* * *}\end{array}$ & $\begin{array}{c}-.283 \\
(.023)^{* * *}\end{array}$ & $\begin{array}{c}-.164 \\
(.002)^{* * *}\end{array}$ & $\begin{array}{c}-.177 \\
(.028)^{* * *}\end{array}$ \\
\hline Log firm size & & & $\begin{array}{c}.050 \\
(.003)^{* * *}\end{array}$ & $\begin{array}{c}.042 \\
(.002)^{* * *}\end{array}$ & $\begin{array}{c}.024 \\
(.004)^{* * *}\end{array}$ & $\begin{array}{c}.072 \\
(.0004)^{* * *}\end{array}$ & $\begin{array}{c}.065 \\
(.006)^{* * *}\end{array}$ \\
\hline No. establishments & & & $\begin{array}{c}-.001 \\
(.0006)^{* *}\end{array}$ & $\begin{array}{r}-.0002 \\
(.0005)\end{array}$ & $\begin{array}{c}.001 \\
(.0007)^{*}\end{array}$ & $\begin{array}{l}.00008 \\
(.00007)\end{array}$ & $\begin{array}{c}.00002 \\
(.0009)\end{array}$ \\
\hline Foreign & & & $\begin{array}{c}.080 \\
(.012)^{* * *}\end{array}$ & $\begin{array}{c}.034 \\
(.007)^{* * *}\end{array}$ & $\begin{array}{c}.019 \\
(.008)^{* *}\end{array}$ & $\begin{array}{c}.028 \\
(.0007)^{* * *}\end{array}$ & $\begin{array}{l}.015 \\
(.009)^{*}\end{array}$ \\
\hline Worker controls & & $\mathrm{x}$ & $\mathrm{x}$ & $\mathrm{x}$ & $\mathrm{x}$ & $\mathrm{x}$ & $\mathrm{x}$ \\
\hline Firm controls & & & $\mathrm{x}$ & $\mathrm{x}$ & $\mathrm{x}$ & $\mathrm{x}$ & $\mathrm{x}$ \\
\hline Worker fixed effects & & & & $\mathrm{x}$ & & $\mathrm{x}$ & \\
\hline Firm fixed effects & & & & & $\mathrm{x}$ & $\mathrm{x}$ & \\
\hline Spell fixed effects & & & & & & & $\mathrm{x}$ \\
\hline Obs. & 5996121 & 5886189 & 5521063 & 5521063 & 5521063 & 5521063 & 5521063 \\
\hline$R^{2}$ & .115 & .494 & .569 & .909 & .678 & .176 & .925 \\
\hline
\end{tabular}

Notes: Source: Author's calculations based on Quadros de Pessoal and INE trade data. Robust standard errors, allowing for clustering at the firm level (except in specification 4, which allow for clustering at the worker level). Significance levels: *** $1 \%$; ** $5 \%$; * $10 \%$. 
Table 13: Worker-level analysis - $\mathbf{X}$ as percentage of sales

\begin{tabular}{|c|c|c|c|c|c|c|c|}
\hline & $(1)$ & $(2)$ & $(3)$ & $(4)$ & $(5)$ & $(6)$ & $(7)$ \\
\hline $\mathrm{X} / \mathrm{S}$ & $\begin{array}{c}.088 \\
(.023)^{* * *}\end{array}$ & $\begin{array}{c}.100 \\
(.014)^{* * *}\end{array}$ & $\begin{array}{c}-.019 \\
(.009)^{* *}\end{array}$ & $\begin{array}{l}.008 \\
(.008)\end{array}$ & $\begin{array}{c}.019 \\
(.009)^{* *}\end{array}$ & $\begin{array}{c}.022 \\
(.0009)^{* * *}\end{array}$ & $\begin{array}{l}.019 \\
(.013)\end{array}$ \\
\hline Schooling & & $\begin{array}{c}.098 \\
(.001)^{* * *}\end{array}$ & $\begin{array}{c}.077 \\
(.0007)^{* * *}\end{array}$ & $\begin{array}{c}.034 \\
(.0006)^{* * *}\end{array}$ & $\begin{array}{c}.070 \\
(.0006)^{* * *}\end{array}$ & $\begin{array}{c}.011 \\
(.0003)^{* * *}\end{array}$ & $\begin{array}{c}.031 \\
(.0007)^{* * *}\end{array}$ \\
\hline Experience & & $\begin{array}{c}.032 \\
(.0005)^{* * *}\end{array}$ & $\begin{array}{c}.030 \\
(.0003)^{* * *}\end{array}$ & $\begin{array}{c}.044 \\
(.0007)^{* * *}\end{array}$ & $\begin{array}{c}.028 \\
(.0002)^{* * *}\end{array}$ & $\begin{array}{c}.021 \\
(.0003)^{* * *}\end{array}$ & $\begin{array}{c}.041 \\
(.001)^{* * *}\end{array}$ \\
\hline$\left(\right.$ Experience $\left.^{2}\right) / 100$ & & $\begin{array}{c}-.037 \\
(.0007)^{* * *}\end{array}$ & $\begin{array}{c}-.036 \\
(.0005)^{* * *}\end{array}$ & $\begin{array}{c}-.032 \\
(.001)^{* * *}\end{array}$ & $\begin{array}{c}-.033 \\
(.0004)^{* * *}\end{array}$ & $\begin{array}{c}-.030 \\
(.0002)^{* * *}\end{array}$ & $\begin{array}{c}-.028 \\
(.001)^{* * *}\end{array}$ \\
\hline Tenure & & $\begin{array}{c}.014 \\
(.0006)^{* * *}\end{array}$ & $\begin{array}{c}.011 \\
(.0004)^{* * *}\end{array}$ & $\begin{array}{c}.004 \\
(.0004)^{* * *}\end{array}$ & $\begin{array}{c}.011 \\
(.0003)^{* * *}\end{array}$ & $\begin{array}{c}.004 \\
(.00008)^{* * *}\end{array}$ & $\begin{array}{c}.004 \\
(.0006)^{* * *}\end{array}$ \\
\hline$\left(\right.$ Tenure $\left.^{2}\right) / 100$ & & $\begin{array}{c}-.020 \\
(.002)^{* * *}\end{array}$ & $\begin{array}{c}-.018 \\
(.001)^{* * *}\end{array}$ & $\begin{array}{c}-.012 \\
(.001)^{* * *}\end{array}$ & $\begin{array}{c}-.019 \\
(.0009)^{* * *}\end{array}$ & $\begin{array}{c}-.011 \\
(.0002)^{* * *}\end{array}$ & $\begin{array}{c}-.012 \\
(.002)^{* * *}\end{array}$ \\
\hline Female & & $\begin{array}{c}-.295 \\
(.005)^{* * *}\end{array}$ & $\begin{array}{c}-.261 \\
(.004)^{* * *}\end{array}$ & & $\begin{array}{c}-.236 \\
(.002)^{* * *}\end{array}$ & & \\
\hline Log hours & & $\begin{array}{c}-.195 \\
(.053)^{* * *}\end{array}$ & $\begin{array}{c}-.356 \\
(.031)^{* * *}\end{array}$ & $\begin{array}{c}-.208 \\
(.024)^{* * *}\end{array}$ & $\begin{array}{c}-.309 \\
(.022)^{* * *}\end{array}$ & $\begin{array}{c}-.195 \\
(.002)^{* * *}\end{array}$ & $\begin{array}{c}-.206 \\
(.027)^{* * *}\end{array}$ \\
\hline Log firm size & & & $\begin{array}{c}.065 \\
(.003)^{* * *}\end{array}$ & $\begin{array}{c}.046 \\
(.002)^{* * *}\end{array}$ & $\begin{array}{c}.027 \\
(.005)^{* * *}\end{array}$ & $\begin{array}{c}.076 \\
(.0005)^{* * *}\end{array}$ & $\begin{array}{c}.068 \\
(.007)^{* * *}\end{array}$ \\
\hline No. establishments & & & $\begin{array}{c}-.002 \\
(.0006)^{* * *}\end{array}$ & $\begin{array}{c}-.0003 \\
(.0006)\end{array}$ & $\begin{array}{c}.001 \\
(.0007)^{*}\end{array}$ & $\begin{array}{c}-.00006 \\
(.00008)\end{array}$ & $\begin{array}{r}-.0002 \\
(.0008)\end{array}$ \\
\hline Foreign & & & $\begin{array}{c}.096 \\
(.012)^{* * *}\end{array}$ & $\begin{array}{c}.032 \\
(.008)^{* * *}\end{array}$ & $\begin{array}{c}.020 \\
(.008)^{* *}\end{array}$ & $\begin{array}{c}.024 \\
(.0008)^{* * *}\end{array}$ & $\begin{array}{l}.009 \\
(.010)\end{array}$ \\
\hline Worker controls & & $\mathrm{x}$ & $\mathrm{x}$ & $\mathrm{x}$ & $\mathrm{x}$ & $\mathrm{x}$ & $\mathrm{x}$ \\
\hline Firm controls & & & $\mathrm{x}$ & $\mathrm{x}$ & $\mathrm{x}$ & $\mathrm{x}$ & $\mathrm{x}$ \\
\hline Worker fixed effects & & & & $\mathrm{x}$ & & $\mathrm{x}$ & \\
\hline Firm fixed effects & & & & & $\mathrm{x}$ & $\mathrm{x}$ & \\
\hline Spell fixed effects & & & & & & & $\mathrm{x}$ \\
\hline Obs. & 5087050 & 4996201 & 4713266 & 4713266 & 4713266 & 4713266 & 4713266 \\
\hline$R^{2}$ & .028 & .467 & .569 & .913 & .678 & .18 & .927 \\
\hline
\end{tabular}

Notes: Source: Author's calculations based on Quadros de Pessoal and INE trade data. Robust standard errors, allowing for clustering at the firm level (except in specification 4, which allow for clustering at the worker level). Significance levels: *** $1 \%$; ${ }^{* *} 5 \%$; $10 \%$. 
Table 14: Worker-level analysis - $\mathbf{X}$ and $\mathbf{M}$ as percentage of sales

\begin{tabular}{|c|c|c|c|c|c|c|c|}
\hline & (1) & $(2)$ & (3) & (4) & $(5)$ & (6) & $(7)$ \\
\hline$\overline{\mathrm{X} / \mathrm{S}}$ & $\begin{array}{l}.005 \\
(.024)\end{array}$ & $\begin{array}{c}.056 \\
(.014)^{* * *}\end{array}$ & $\begin{array}{c}-.022 \\
(.009)^{* *}\end{array}$ & $\begin{array}{l}.006 \\
(.008)\end{array}$ & $\begin{array}{c}.017 \\
(.009)^{*}\end{array}$ & $\begin{array}{c}.020 \\
(.0009)^{* * *}\end{array}$ & $\begin{array}{l}.017 \\
(.013)\end{array}$ \\
\hline $\mathrm{M} / \mathrm{S}$ & $\begin{array}{c}.434 \\
(.035)^{* * *}\end{array}$ & $\begin{array}{c}.238 \\
(.021)^{* * *}\end{array}$ & $\begin{array}{c}.053 \\
(.010)^{* * *}\end{array}$ & $\begin{array}{c}.012 \\
(.005)^{* *}\end{array}$ & $\begin{array}{l}.005 \\
(.005)\end{array}$ & $\begin{array}{c}.008 \\
(.0007)^{* * *}\end{array}$ & $\begin{array}{l}.003 \\
(.006)\end{array}$ \\
\hline Schooling & & $\begin{array}{c}.095 \\
(.001)^{* * *}\end{array}$ & $\begin{array}{c}.077 \\
(.0007)^{* * *}\end{array}$ & $\begin{array}{c}.034 \\
(.0006)^{* * *}\end{array}$ & $\begin{array}{c}.070 \\
(.0006)^{* * *}\end{array}$ & $\begin{array}{c}.011 \\
(.0003)^{* * *}\end{array}$ & $\begin{array}{c}.031 \\
(.0007)^{* * *}\end{array}$ \\
\hline Experience & & $\begin{array}{c}.032 \\
(.0005)^{* * *}\end{array}$ & $\begin{array}{c}.030 \\
(.0003)^{* * *}\end{array}$ & $\begin{array}{c}.043 \\
(.0007)^{* * *}\end{array}$ & $\begin{array}{c}.028 \\
(.0002)^{* * *}\end{array}$ & $\begin{array}{c}.021 \\
(.0003)^{* * *}\end{array}$ & $\begin{array}{c}.041 \\
(.001)^{* * *}\end{array}$ \\
\hline$\left(\right.$ Experience $\left.^{2}\right) / 100$ & & $\begin{array}{c}-.037 \\
(.0007)^{* * *}\end{array}$ & $\begin{array}{c}-.036 \\
(.0005)^{* * *}\end{array}$ & $\begin{array}{c}-.032 \\
(.001)^{* * *}\end{array}$ & $\begin{array}{c}-.033 \\
(.0004)^{* * *}\end{array}$ & $\begin{array}{c}-.030 \\
(.0002)^{* * *}\end{array}$ & $\begin{array}{c}-.028 \\
(.001)^{* * *}\end{array}$ \\
\hline Tenure & & $\begin{array}{c}.014 \\
(.0005)^{* * *}\end{array}$ & $\begin{array}{c}.011 \\
(.0004)^{* * *}\end{array}$ & $\begin{array}{c}.004 \\
(.0004)^{* * *}\end{array}$ & $\begin{array}{c}.011 \\
(.0003)^{* * *}\end{array}$ & $\begin{array}{c}.004 \\
(.00008)^{* * *}\end{array}$ & $\begin{array}{c}.004 \\
(.0006)^{* * *}\end{array}$ \\
\hline$\left(\right.$ Tenure $\left.^{2}\right) / 100$ & & $\begin{array}{c}-.019 \\
(.002)^{* * *}\end{array}$ & $\begin{array}{c}-.018 \\
(.001)^{* * *}\end{array}$ & $\begin{array}{c}-.012 \\
(.001)^{* * *}\end{array}$ & $\begin{array}{c}-.019 \\
(.0009)^{* * *}\end{array}$ & $\begin{array}{c}-.011 \\
(.0002)^{* * *}\end{array}$ & $\begin{array}{c}-.012 \\
(.002)^{* * *}\end{array}$ \\
\hline Female & & $\begin{array}{c}-.292 \\
(.004)^{* * *}\end{array}$ & $\begin{array}{c}-.261 \\
(.004)^{* * *}\end{array}$ & & $\begin{array}{c}-.236 \\
(.002)^{* * *}\end{array}$ & & \\
\hline Log hours & & $\begin{array}{c}-.239 \\
(.050)^{* * *}\end{array}$ & $\begin{array}{c}-.357 \\
(.030)^{* * *}\end{array}$ & $\begin{array}{c}-.208 \\
(.024)^{* * *}\end{array}$ & $\begin{array}{c}-.308 \\
(.022)^{* * *}\end{array}$ & $\begin{array}{c}-.195 \\
(.002)^{* * *}\end{array}$ & $\begin{array}{c}-.206 \\
(.027)^{* * *}\end{array}$ \\
\hline Log firm size & & & $\begin{array}{c}.064 \\
(.003)^{* * *}\end{array}$ & $\begin{array}{c}.046 \\
(.002)^{* * *}\end{array}$ & $\begin{array}{c}.027 \\
(.005)^{* * *}\end{array}$ & $\begin{array}{c}.076 \\
(.0005)^{* * *}\end{array}$ & $\begin{array}{c}.068 \\
(.007)^{* * *}\end{array}$ \\
\hline No. establishments & & & $\begin{array}{c}-.002 \\
(.0006)^{* * *}\end{array}$ & $\begin{array}{c}-.0003 \\
(.0006)\end{array}$ & $\begin{array}{c}.001 \\
(.0007)^{*}\end{array}$ & $\begin{array}{c}-.00005 \\
(.00008)\end{array}$ & $\begin{array}{r}-.0002 \\
(.0008)\end{array}$ \\
\hline Foreign & & & $\begin{array}{c}.090 \\
(.012)^{* * *}\end{array}$ & $\begin{array}{c}.031 \\
(.008)^{* * *}\end{array}$ & $\begin{array}{c}.020 \\
(.008)^{* *}\end{array}$ & $\begin{array}{c}.023 \\
(.0008)^{* * *}\end{array}$ & $\begin{array}{l}.009 \\
(.010)\end{array}$ \\
\hline Worker controls & & $\mathrm{x}$ & $\mathrm{x}$ & $\mathrm{x}$ & $\mathrm{x}$ & $\mathrm{x}$ & $\mathrm{x}$ \\
\hline Firm controls & & & $\mathrm{x}$ & $\mathrm{x}$ & $\mathrm{x}$ & $\mathrm{x}$ & $\mathrm{x}$ \\
\hline Worker fixed effects & & & & $\mathrm{x}$ & & $\mathrm{x}$ & \\
\hline Firm fixed effects & & & & & $\mathrm{x}$ & $\mathrm{x}$ & \\
\hline Spell fixed effects & & & & & & & $\mathrm{x}$ \\
\hline Obs. & 5083547 & 4992754 & 4709819 & 4709819 & 4709819 & 4709819 & 4709819 \\
\hline$R^{2}$ & .066 & .478 & .569 & .912 & .678 & .18 & .927 \\
\hline
\end{tabular}

Notes: Source: Author's calculations based on Quadros de Pessoal and INE trade data. Robust standard errors, allowing for clustering at the firm level (except in specification 4, which allow for clustering at the worker level). Significance levels: $* * * 1 \% ; * * 5 \% ; * 10 \%$. 


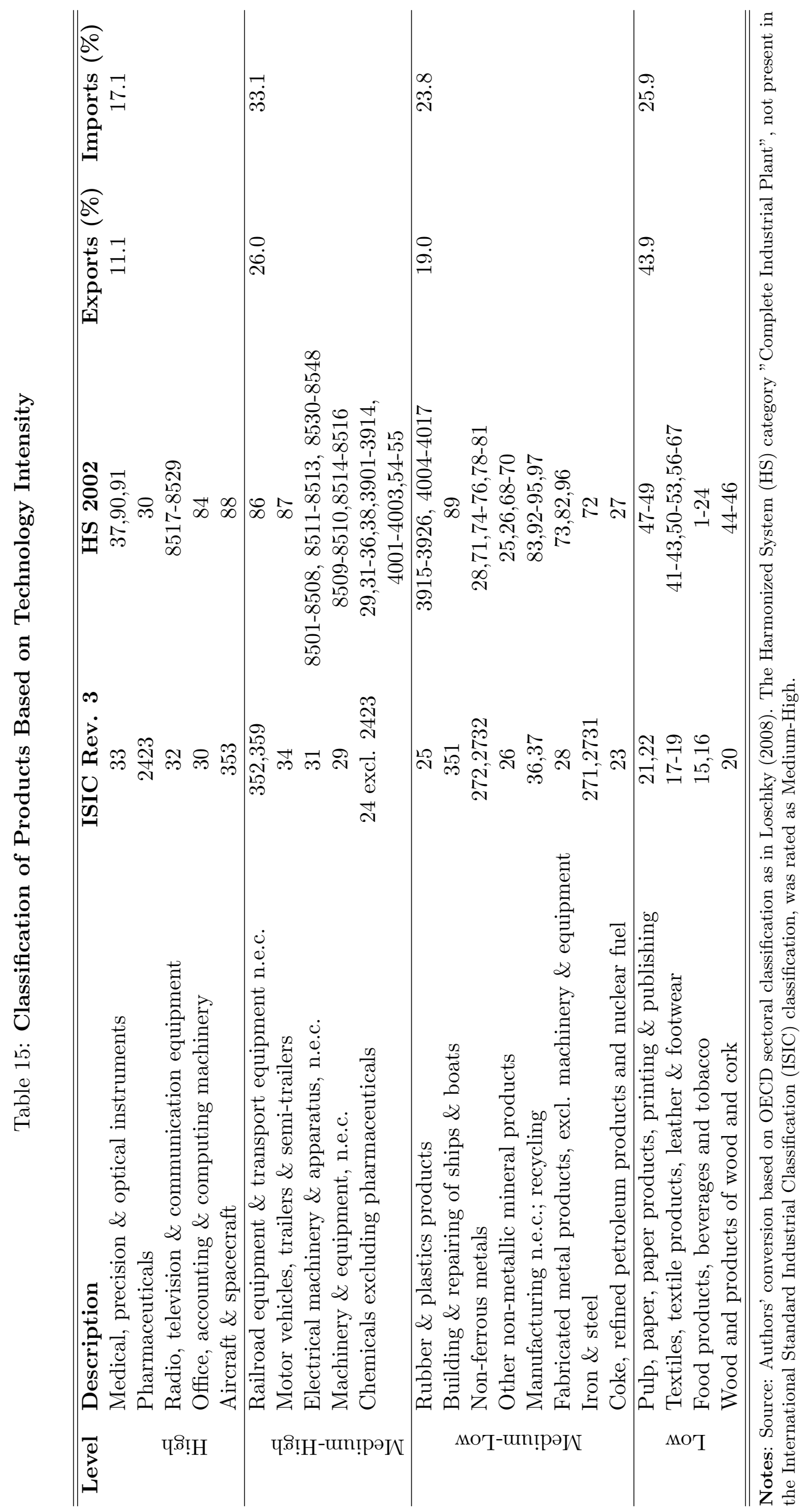


Table 16: Firm-level analysis - X by product type (\% of sales)

\begin{tabular}{|c|c|c|c|c|}
\hline & $(1)$ & $(2)$ & $(3)$ & $(4)$ \\
\hline$X^{\text {LowTech }} / S$ & $\begin{array}{c}.090 \\
(.008)^{* * *}\end{array}$ & $\begin{array}{c}.161 \\
(.006)^{* * *}\end{array}$ & $\begin{array}{l}-.013 \\
(.006)^{* *}\end{array}$ & $\begin{array}{l}.002 \\
(.008)\end{array}$ \\
\hline$X^{\text {MedLowTech }} / S$ & $\begin{array}{c}.429 \\
(.017)^{* * *}\end{array}$ & $\begin{array}{c}.301 \\
(.012)^{* * *}\end{array}$ & $\begin{array}{c}.061 \\
(.011)^{* * *}\end{array}$ & $\begin{array}{l}.028 \\
(.014)^{* *}\end{array}$ \\
\hline$X^{\text {MedHighTech }} / S$ & $\begin{array}{c}.780 \\
(.037)^{* * *}\end{array}$ & $\begin{array}{c}.523 \\
(.027)^{* * *}\end{array}$ & $\begin{array}{l}.116 \\
(.023)^{* * *}\end{array}$ & $\begin{array}{l}.014 \\
(.024)\end{array}$ \\
\hline$X^{\text {HighTech }} / S$ & $\begin{array}{c}.886 \\
(.028)^{* * *}\end{array}$ & $\begin{array}{c}.568 \\
(.021)^{* * *}\end{array}$ & $\begin{array}{l}.261 \\
(.022)^{* * *}\end{array}$ & $\begin{array}{l}.044 \\
(.025)^{*}\end{array}$ \\
\hline Schooling & & $\begin{array}{c}.069 \\
(.0008)^{* * *}\end{array}$ & $\begin{array}{c}.069 \\
(.0008)^{* * *}\end{array}$ & $\begin{array}{c}.028 \\
(.0009)^{* * *}\end{array}$ \\
\hline Experience & & $\begin{array}{c}.036 \\
(.0005)^{* * *}\end{array}$ & $\begin{array}{c}.024 \\
(.0006)^{* * *}\end{array}$ & $\begin{array}{c}.017 \\
(.0006)^{* * *}\end{array}$ \\
\hline$\left(\right.$ Experience $\left.^{2}\right) / 100$ & & $\begin{array}{c}-.053 \\
(.0009)^{* * *}\end{array}$ & $\begin{array}{l}-.029 \\
(.001)^{* * *}\end{array}$ & $\begin{array}{l}-.019 \\
(.001)^{* * *}\end{array}$ \\
\hline Tenure & & $\begin{array}{c}.011 \\
(.0004)^{* * *}\end{array}$ & $\begin{array}{c}.004 \\
(.0005)^{* * *}\end{array}$ & $\begin{array}{c}.006 \\
(.0006)^{* * * *}\end{array}$ \\
\hline$\left(\right.$ Tenure $\left.^{2}\right) / 100$ & & $\begin{array}{l}-.015 \\
(.002)^{* * *}\end{array}$ & $\begin{array}{l}-.001 \\
(.002)\end{array}$ & $\begin{array}{l}-.011 \\
(.002)^{* * *}\end{array}$ \\
\hline Female share & & $\begin{array}{l}-.179 \\
(.002)^{* * *}\end{array}$ & $\begin{array}{l}-.256 \\
(.003)^{* * *}\end{array}$ & $\begin{array}{l}-.152 \\
(.006)^{* * *}\end{array}$ \\
\hline Log hours & & $\begin{array}{l}-.631 \\
(.021)^{* * *}\end{array}$ & $\begin{array}{l}-.716 \\
(.023)^{* * *}\end{array}$ & $\begin{array}{l}-.748 \\
(.016)^{* * *}\end{array}$ \\
\hline Log firm size & & & $\begin{array}{l}.081 \\
(.001)^{* * *}\end{array}$ & $\begin{array}{c}.020 \\
(.003)^{* * *}\end{array}$ \\
\hline No. establishments & & & $\begin{array}{c}-.0008 \\
(.0009)\end{array}$ & $\begin{array}{c}.003 \\
(.001)^{* *}\end{array}$ \\
\hline Foreign & & & $\begin{array}{c}.270 \\
(.011)^{* * *}\end{array}$ & $\begin{array}{c}.037 \\
(.011)^{* * *}\end{array}$ \\
\hline Worker controls & & $\mathrm{x}$ & $\mathrm{x}$ & $\mathrm{x}$ \\
\hline Firm controls & & & $\mathrm{x}$ & $\mathrm{x}$ \\
\hline Firm fixed effects & & & & $\mathrm{x}$ \\
\hline Obs. & 307387 & 302101 & 222869 & 222869 \\
\hline$R^{2}$ & .089 & .38 & .453 & .84 \\
\hline
\end{tabular}

Notes: Source: Author's calculations based on Quadros de Pessoal and INE trade data. Robust standard errors, allowing for clustering at the firm level. Significance levels: *** $1 \%$; ** $5 \%$; $10 \%$. 
Table 17: Firm-level analysis - $\mathrm{X}$ and $\mathbf{M}$ by product type (\% of sales)

\begin{tabular}{|c|c|c|c|c|}
\hline & $(1)$ & $(2)$ & $(3)$ & $(4)$ \\
\hline$X^{\text {LowTech }} / S$ & $\begin{array}{c}.054 \\
(.008)^{* * *}\end{array}$ & $\begin{array}{c}.140 \\
(.006)^{* * *}\end{array}$ & $\begin{array}{l}-.010 \\
(.006)^{*}\end{array}$ & $\begin{array}{l}.0008 \\
(.008)\end{array}$ \\
\hline$X^{\text {MedLowTech }} / S$ & $\begin{array}{c}.351 \\
(.017)^{* * *}\end{array}$ & $\begin{array}{c}.255 \\
(.012)^{* * *}\end{array}$ & $\begin{array}{c}.047 \\
(.011)^{* * *}\end{array}$ & $\begin{array}{l}.028 \\
(.013)^{* *}\end{array}$ \\
\hline$X^{\text {MedHighTech }} / S$ & $\begin{array}{c}.502 \\
(.041)^{* * *}\end{array}$ & $\begin{array}{l}.347 \\
(.029)^{* * *}\end{array}$ & $\begin{array}{c}.046 \\
(.024)^{* *}\end{array}$ & $\begin{array}{l}.013 \\
(.024)\end{array}$ \\
\hline$X^{\text {HighTech }} / S$ & $\begin{array}{l}.784 \\
(.030)^{* * *}\end{array}$ & $\begin{array}{c}.513 \\
(.022)^{* * *}\end{array}$ & $\begin{array}{c}.245 \\
(.023)^{* * *}\end{array}$ & $\begin{array}{l}.044 \\
(.025)^{*}\end{array}$ \\
\hline$M^{\text {LowTech }} / S$ & $\begin{array}{l}.244 \\
(.034)^{* * *}\end{array}$ & $\begin{array}{l}.162 \\
(.024)^{* * *}\end{array}$ & $\begin{array}{c}.033 \\
(.011)^{* * *}\end{array}$ & $\begin{array}{l}.007 \\
(.006)\end{array}$ \\
\hline$M^{\text {MedLowTech }} / S$ & $\begin{array}{c}.455 \\
(.055)^{* * *}\end{array}$ & $\begin{array}{l}.295 \\
(.037)^{* * *}\end{array}$ & $\begin{array}{l}.151 \\
(.021)^{* * *}\end{array}$ & $\begin{array}{l}.011 \\
(.009)\end{array}$ \\
\hline$M^{M e d H i g h T e c h} / S$ & $\begin{array}{c}.653 \\
(.072)^{* * *}\end{array}$ & $\begin{array}{c}.450 \\
(.045)^{* * *}\end{array}$ & $\begin{array}{c}.241 \\
(.027)^{* * *}\end{array}$ & $\begin{array}{c}-.006 \\
(.009)\end{array}$ \\
\hline$M^{\text {HighTech }} / S$ & $\begin{array}{c}.452 \\
(.059)^{* * *}\end{array}$ & $\begin{array}{l}.300 \\
(.039)^{* * *}\end{array}$ & $\begin{array}{l}.162 \\
(.023)^{* * *}\end{array}$ & $\begin{array}{l}-.003 \\
(.012)\end{array}$ \\
\hline Schooling & & $\begin{array}{c}.065 \\
(.0008)^{* * *}\end{array}$ & $\begin{array}{c}.067 \\
(.0008)^{* * *}\end{array}$ & $\begin{array}{c}.028 \\
(.0009)^{* * *}\end{array}$ \\
\hline Experience & & $\begin{array}{c}.034 \\
(.0005)^{* * *}\end{array}$ & $\begin{array}{c}.024 \\
(.0006)^{* * *}\end{array}$ & $\begin{array}{c}.017 \\
(.0006)^{* * *}\end{array}$ \\
\hline$\left(\right.$ Experience $\left.^{2}\right) / 100$ & & $\begin{array}{c}-.051 \\
(.0009)^{* * *}\end{array}$ & $\begin{array}{l}-.029 \\
(.001)^{* * *}\end{array}$ & $\begin{array}{l}-.019 \\
(.001)^{* * *}\end{array}$ \\
\hline Tenure & & $\begin{array}{c}.010 \\
(.0004)^{* * *}\end{array}$ & $\begin{array}{c}.004 \\
(.0005)^{* * *}\end{array}$ & $\begin{array}{c}.006 \\
(.0006)^{* * *}\end{array}$ \\
\hline$\left(\right.$ Tenure $\left.^{2}\right) / 100$ & & $\begin{array}{l}-.013 \\
(.002)^{* * *}\end{array}$ & $\begin{array}{l}-.001 \\
(.002)\end{array}$ & $\begin{array}{l}-.011 \\
(.002)^{* * *}\end{array}$ \\
\hline Female share & & $\begin{array}{l}-.179 \\
(.002)^{* * *}\end{array}$ & $\begin{array}{l}-.253 \\
(.003)^{* * *}\end{array}$ & $\begin{array}{l}-.152 \\
(.006)^{* * *}\end{array}$ \\
\hline Log hours & & $\begin{array}{l}-.649 \\
(.020)^{* * *}\end{array}$ & $\begin{array}{l}-.722 \\
(.023)^{* * *}\end{array}$ & $\begin{array}{l}-.747 \\
(.016)^{* * *}\end{array}$ \\
\hline Log firm size & & & $\begin{array}{l}.078 \\
(.001)^{* * *}\end{array}$ & $\begin{array}{c}.020 \\
(.003)^{* * * *}\end{array}$ \\
\hline No. establishments & & & $\begin{array}{r}-.00066 \\
(.0009)\end{array}$ & $\begin{array}{c}.003 \\
(.001)^{* *}\end{array}$ \\
\hline Foreign & & & $\begin{array}{c}.240 \\
(.011)^{* * *}\end{array}$ & $\begin{array}{c}.038 \\
(.011)^{* * *}\end{array}$ \\
\hline Worker controls & & $\mathrm{x}$ & $\mathrm{x}$ & $\mathrm{x}$ \\
\hline Firm controls & & & $\mathrm{x}$ & $\mathrm{x}$ \\
\hline Firm fixed effects & & & & $\mathrm{x}$ \\
\hline Obs. & 307323 & 302039 & 222807 & 222807 \\
\hline$R^{2}$ & .125 & .395 & .457 & .84 \\
\hline
\end{tabular}

Notes: Source: Author's calculations based on Quadros de Pessoal and INE trade data. Robust standard errors, allowing for clustering at the firm level. Significance levels: ${ }^{* *} 1 \%$; ${ }^{* *} 5 \%$; ${ }^{*} 10 \%$. 
Table 18: Worker-level analysis - $\mathbf{X}$ by product type (\% of sales)

\begin{tabular}{|c|c|c|c|c|c|c|c|}
\hline & $(1)$ & $(2)$ & $(3)$ & $(4)$ & $(5)$ & $(6)$ & $(7)$ \\
\hline$X^{\text {LowTech }} / S$ & $\begin{array}{c}-.118 \\
(.028)^{* * *}\end{array}$ & $\begin{array}{l}-.004 \\
(.016)\end{array}$ & $\begin{array}{l}.0006 \\
(.011)\end{array}$ & $\begin{array}{l}-.002 \\
(.007)\end{array}$ & $\begin{array}{c}.019 \\
(.010)^{*}\end{array}$ & $\begin{array}{c}.011 \\
(.001)^{* * *}\end{array}$ & $\begin{array}{l}.013 \\
(.012)\end{array}$ \\
\hline$X^{M e d L o w T e c h} / S$ & $\begin{array}{c}.244 \\
(.034)^{* * *}\end{array}$ & $\begin{array}{c}.180 \\
(.022)^{* * *}\end{array}$ & $\begin{array}{c}-.046 \\
(.019)^{* *}\end{array}$ & $\begin{array}{c}.020 \\
(.011)^{*}\end{array}$ & $\begin{array}{l}.018 \\
(.013)\end{array}$ & $\begin{array}{c}.035 \\
(.002)^{* * *}\end{array}$ & $\begin{array}{l}.019 \\
(.015)\end{array}$ \\
\hline$X^{M e d H i g h T e c h} / S$ & $\begin{array}{c}.450 \\
(.063)^{* * *}\end{array}$ & $\begin{array}{c}.280 \\
(.029)^{* * *}\end{array}$ & $\begin{array}{c}-.070 \\
(.030)^{* *}\end{array}$ & $\begin{array}{l}.012 \\
(.031)\end{array}$ & $\begin{array}{r}-.003 \\
(.034)\end{array}$ & $\begin{array}{c}.037 \\
(.002)^{* * *}\end{array}$ & $\begin{array}{l}.005 \\
(.053)\end{array}$ \\
\hline$X^{\text {HighTech }} / S$ & $\begin{array}{c}.475 \\
(.031)^{* * *}\end{array}$ & $\begin{array}{c}.281 \\
(.033)^{* * *}\end{array}$ & $\begin{array}{r}-.026 \\
(.036)\end{array}$ & $\begin{array}{c}.044 \\
(.019)^{* *}\end{array}$ & $\begin{array}{c}.055 \\
(.024)^{* *}\end{array}$ & $\begin{array}{c}.057 \\
(.002)^{* * *}\end{array}$ & $\begin{array}{c}.071 \\
(.029)^{* *}\end{array}$ \\
\hline Schooling & & $\begin{array}{c}.095 \\
(.001)^{* * *}\end{array}$ & $\begin{array}{c}.077 \\
(.0007)^{* * *}\end{array}$ & $\begin{array}{c}.034 \\
(.0006)^{* * *}\end{array}$ & $\begin{array}{c}.070 \\
(.0006)^{* * *}\end{array}$ & $\begin{array}{c}.011 \\
(.0003)^{* * *}\end{array}$ & $\begin{array}{c}.031 \\
(.0007)^{* * *}\end{array}$ \\
\hline Experience & & $\begin{array}{c}.032 \\
(.0005)^{* * *}\end{array}$ & $\begin{array}{c}.030 \\
(.0003)^{* * *}\end{array}$ & $\begin{array}{c}.043 \\
(.0007)^{* * *}\end{array}$ & $\begin{array}{c}.028 \\
(.0002)^{* * *}\end{array}$ & $\begin{array}{c}.021 \\
(.0003)^{* * *}\end{array}$ & $\begin{array}{c}.041 \\
(.001)^{* * *}\end{array}$ \\
\hline$\left(\right.$ Experience $\left.^{2}\right) / 100$ & & $\begin{array}{c}-.038 \\
(.0007)^{* * *}\end{array}$ & $\begin{array}{c}-.036 \\
(.0005)^{* * *}\end{array}$ & $\begin{array}{c}-.032 \\
(.001)^{* * *}\end{array}$ & $\begin{array}{c}-.033 \\
(.0004)^{* * *}\end{array}$ & $\begin{array}{c}-.030 \\
(.0002)^{* * *}\end{array}$ & $\begin{array}{c}-.028 \\
(.001)^{* * *}\end{array}$ \\
\hline Tenure & & $\begin{array}{c}.015 \\
(.0006)^{* * *}\end{array}$ & $\begin{array}{c}.010 \\
(.0004)^{* * *}\end{array}$ & $\begin{array}{c}.004 \\
(.0004)^{* * *}\end{array}$ & $\begin{array}{c}.011 \\
(.0003)^{* * *}\end{array}$ & $\begin{array}{c}.004 \\
(.00008)^{* * *}\end{array}$ & $\begin{array}{c}.004 \\
(.0006)^{* * *}\end{array}$ \\
\hline$\left(\right.$ Tenure $\left.^{2}\right) / 100$ & & $\begin{array}{c}-.020 \\
(.002)^{* * *}\end{array}$ & $\begin{array}{c}-.018 \\
(.001)^{* * *}\end{array}$ & $\begin{array}{c}-.012 \\
(.001)^{* * *}\end{array}$ & $\begin{array}{c}-.019 \\
(.0009)^{* * *}\end{array}$ & $\begin{array}{c}-.011 \\
(.0002)^{* * *}\end{array}$ & $\begin{array}{c}-.012 \\
(.002)^{* * *}\end{array}$ \\
\hline Female & & $\begin{array}{c}-.284 \\
(.005)^{* * *}\end{array}$ & $\begin{array}{c}-.261 \\
(.004)^{* * *}\end{array}$ & & $\begin{array}{c}-.236 \\
(.002)^{* * *}\end{array}$ & & \\
\hline Log hours & & $\begin{array}{c}-.223 \\
(.051)^{* * *}\end{array}$ & $\begin{array}{c}-.355 \\
(.030)^{* * *}\end{array}$ & $\begin{array}{c}-.208 \\
(.024)^{* * *}\end{array}$ & $\begin{array}{c}-.309 \\
(.022)^{* * *}\end{array}$ & $\begin{array}{c}-.195 \\
(.002)^{* * *}\end{array}$ & $\begin{array}{c}-.206 \\
(.027)^{* * *}\end{array}$ \\
\hline Log firm size & & & $\begin{array}{c}.066 \\
(.003)^{* * *}\end{array}$ & $\begin{array}{c}.046 \\
(.002)^{* * *}\end{array}$ & $\begin{array}{c}.027 \\
(.005)^{* * *}\end{array}$ & $\begin{array}{c}.076 \\
(.0005)^{* * *}\end{array}$ & $\begin{array}{c}.068 \\
(.007)^{* * *}\end{array}$ \\
\hline No. establishments & & & $\begin{array}{c}-.002 \\
(.0006)^{* * *}\end{array}$ & $\begin{array}{c}-.0003 \\
(.0006)\end{array}$ & $\begin{array}{c}.001 \\
(.0007)^{*}\end{array}$ & $\begin{array}{c}-.00004 \\
(.00008)\end{array}$ & $\begin{array}{c}-.0002 \\
(.0008)\end{array}$ \\
\hline Foreign & & & $\begin{array}{c}.099 \\
(.012)^{* * *}\end{array}$ & $\begin{array}{c}.030 \\
(.008)^{* * *}\end{array}$ & $\begin{array}{c}.019 \\
(.008)^{* *}\end{array}$ & $\begin{array}{c}.022 \\
(.0008)^{* * *}\end{array}$ & $\begin{array}{l}.008 \\
(.010)\end{array}$ \\
\hline Worker controls & & $\mathrm{x}$ & $\mathrm{x}$ & $\mathrm{x}$ & $\mathrm{x}$ & $\mathrm{x}$ & $\mathrm{x}$ \\
\hline Firm controls & & & $\mathrm{x}$ & $\mathrm{x}$ & $\mathrm{x}$ & $\mathrm{x}$ & $\mathrm{x}$ \\
\hline Worker fixed effects & & & & $\mathrm{x}$ & & $\mathrm{x}$ & \\
\hline Firm fixed effects & & & & & $\mathrm{x}$ & $\mathrm{x}$ & \\
\hline Spell fixed effects & & & & & & & $\mathrm{x}$ \\
\hline Obs. & 5087050 & 4996201 & 4713266 & 4713266 & 4713266 & 4713266 & 4713266 \\
\hline$R^{2}$ & .065 & .476 & .57 & .913 & .678 & .18 & .927 \\
\hline
\end{tabular}

Notes: Source: Author's calculations based on Quadros de Pessoal and INE trade data. Robust standard errors, allowing for clustering at the firm level (except in specification 4, which allow for clustering at the worker level). Significance levels: *** $1 \%$; ** $5 \%$; * $10 \%$. 
Table 19: Worker-level analysis - $\mathbf{X}$ and $\mathbf{M}$ by product type (\% of sales)

\begin{tabular}{|c|c|c|c|c|c|c|c|}
\hline & (1) & (2) & $(3)$ & $(4)$ & $(5)$ & (6) & $(7)$ \\
\hline$X^{\text {LowTech }} / S$ & $\begin{array}{l}-.123 \\
(.029)^{* * *}\end{array}$ & $\begin{array}{l}-.012 \\
(.017)\end{array}$ & $\begin{array}{l}.002 \\
(.011)\end{array}$ & $\begin{array}{l}-.004 \\
(.007)\end{array}$ & $\begin{array}{c}.017 \\
(.010)^{*}\end{array}$ & $\begin{array}{c}.009 \\
(.001)^{* * *}\end{array}$ & $\begin{array}{l}.011 \\
(.012)\end{array}$ \\
\hline$X^{\text {MedLowTech }} / S$ & $\begin{array}{l}.140 \\
(.034)^{* * *}\end{array}$ & $\begin{array}{l}.130 \\
(.022)^{* * *}\end{array}$ & $\begin{array}{l}-.057 \\
(.019)^{* * *}\end{array}$ & $\begin{array}{l}.015 \\
(.011)\end{array}$ & $\begin{array}{l}.014 \\
(.013)\end{array}$ & $\begin{array}{c}.030 \\
(.002)^{* * *}\end{array}$ & $\begin{array}{l}.015 \\
(.015)\end{array}$ \\
\hline$X^{\text {MedHighTech }} / S$ & $\begin{array}{c}.222 \\
(.073)^{* * *}\end{array}$ & $\begin{array}{c}.163 \\
(.037)^{* * *}\end{array}$ & $\begin{array}{l}-.079 \\
(.030)^{* * *}\end{array}$ & $\begin{array}{l}.009 \\
(.031)\end{array}$ & $\begin{array}{c}-.005 \\
(.034)\end{array}$ & $\begin{array}{c}.033 \\
(.002)^{* * *}\end{array}$ & $\begin{array}{l}.003 \\
(.053)\end{array}$ \\
\hline$X^{\text {HighTech }} / S$ & $\begin{array}{c}.262 \\
(.040)^{* * *}\end{array}$ & $\begin{array}{l}.171 \\
(.026)^{* * *}\end{array}$ & $\begin{array}{l}-.036 \\
(.036)\end{array}$ & $\begin{array}{c}.043 \\
(.019)^{* *}\end{array}$ & $\begin{array}{l}.055 \\
(.024)^{* *}\end{array}$ & $\begin{array}{c}.056 \\
(.002)^{* * *}\end{array}$ & $\begin{array}{l}.072 \\
(.029)^{* *}\end{array}$ \\
\hline$M^{\text {LowTech }} / S$ & $\begin{array}{l}.119 \\
(.033)^{* * *}\end{array}$ & $\begin{array}{l}.092 \\
(.023)^{* * *}\end{array}$ & $\begin{array}{l}.013 \\
(.015)\end{array}$ & $\begin{array}{l}.007 \\
(.007)\end{array}$ & $\begin{array}{l}.007 \\
(.008)\end{array}$ & $\begin{array}{l}.001 \\
(.001)\end{array}$ & $\begin{array}{c}-.0008 \\
(.007)\end{array}$ \\
\hline$M^{\text {MedLowTech }} / S$ & $\begin{array}{c}.542 \\
(.084)^{* * *}\end{array}$ & $\begin{array}{c}.270 \\
(.043)^{* * *}\end{array}$ & $\begin{array}{c}.109 \\
(.023)^{* * *}\end{array}$ & $\begin{array}{c}.028 \\
(.009)^{* * *}\end{array}$ & $\begin{array}{c}.020 \\
(.010)^{*}\end{array}$ & $\begin{array}{c}.026 \\
(.002)^{* * *}\end{array}$ & $\begin{array}{l}.021 \\
(.013)\end{array}$ \\
\hline$M^{M e d H i g h T e c h} / S$ & $\begin{array}{c}.496 \\
(.074)^{* * *}\end{array}$ & $\begin{array}{c}.277 \\
(.048)^{* * *}\end{array}$ & $\begin{array}{l}.071 \\
(.027)^{* * *}\end{array}$ & $\begin{array}{l}.018 \\
(.017)\end{array}$ & $\begin{array}{c}-.003 \\
(.013)\end{array}$ & $\begin{array}{c}.019 \\
(.001)^{* * *}\end{array}$ & $\begin{array}{l}.008 \\
(.017)\end{array}$ \\
\hline$M^{H i g h T e c h} / S$ & $\begin{array}{l}.651 \\
(.097)^{* * *}\end{array}$ & $\begin{array}{c}.361 \\
(.056)^{* * *}\end{array}$ & $\begin{array}{c}.085 \\
(.030)^{* * *}\end{array}$ & $\begin{array}{l}-.002 \\
(.012)\end{array}$ & $\begin{array}{l}-.004 \\
(.009)\end{array}$ & $\begin{array}{l}-.004 \\
(.002)^{* * *}\end{array}$ & $\begin{array}{l}-.013 \\
(.012)\end{array}$ \\
\hline Schooling & & $\begin{array}{c}.093 \\
(.001)^{* * *}\end{array}$ & $\begin{array}{c}.077 \\
(.0007)^{* * *}\end{array}$ & $\begin{array}{c}.034 \\
(.0006)^{* * *}\end{array}$ & $\begin{array}{c}.070 \\
(.0006)^{* * *}\end{array}$ & $\begin{array}{c}.012 \\
(.0003)^{* * *}\end{array}$ & $\begin{array}{c}.031 \\
(.0007)^{* * *}\end{array}$ \\
\hline Experience & & $\begin{array}{c}.032 \\
(.0005)^{* * *}\end{array}$ & $\begin{array}{c}.030 \\
(.0003)^{* * *}\end{array}$ & $\begin{array}{c}.043 \\
(.0007)^{* * *}\end{array}$ & $\begin{array}{c}.028 \\
(.0002)^{* * *}\end{array}$ & $\begin{array}{c}.021 \\
(.0003)^{* * *}\end{array}$ & $\begin{array}{l}.041 \\
(.001)^{* * *}\end{array}$ \\
\hline$\left(\right.$ Experience $\left.^{2}\right) / 100$ & & $\begin{array}{c}-.037 \\
(.0007)^{* * *}\end{array}$ & $\begin{array}{c}-.036 \\
(.0005)^{* * *}\end{array}$ & $\begin{array}{l}-.032 \\
(.001)^{* * *}\end{array}$ & $\begin{array}{c}-.033 \\
(.0004)^{* * *}\end{array}$ & $\begin{array}{c}-.030 \\
(.0002)^{* * *}\end{array}$ & $\begin{array}{l}-.028 \\
(.001)^{* * *}\end{array}$ \\
\hline Tenure & & $\begin{array}{c}.014 \\
(.0005)^{* * *}\end{array}$ & $\begin{array}{c}.010 \\
(.0004)^{* * *}\end{array}$ & $\begin{array}{c}.004 \\
(.0004)^{* * *}\end{array}$ & $\begin{array}{c}.011 \\
(.0003)^{* * *}\end{array}$ & $\begin{array}{c}.004 \\
(.00008)^{* * *}\end{array}$ & $\begin{array}{c}.004 \\
(.0006)^{* * *}\end{array}$ \\
\hline$\left(\right.$ Tenure $\left.^{2}\right) / 100$ & & $\begin{array}{l}-.020 \\
(.001)^{* * *}\end{array}$ & $\begin{array}{l}-.018 \\
(.001)^{* * *}\end{array}$ & $\begin{array}{l}-.012 \\
(.001)^{* * *}\end{array}$ & $\begin{array}{c}-.019 \\
(.0009)^{* * *}\end{array}$ & $\begin{array}{c}-.011 \\
(.0002)^{* * *}\end{array}$ & $\begin{array}{l}-.012 \\
(.002)^{* * *}\end{array}$ \\
\hline Female & & $\begin{array}{l}-.280 \\
(.004)^{* * *}\end{array}$ & $\begin{array}{l}-.260 \\
(.004)^{* * * *}\end{array}$ & & $\begin{array}{l}-.236 \\
(.002)^{* * *}\end{array}$ & & \\
\hline Log hours & & $\begin{array}{c}-.264 \\
(.048)^{* * *}\end{array}$ & $\begin{array}{c}-.359 \\
(.030)^{* * *}\end{array}$ & $\begin{array}{l}-.208 \\
(.024)^{* * *}\end{array}$ & $\begin{array}{l}-.308 \\
(.022)^{* * *}\end{array}$ & $\begin{array}{l}-.195 \\
(.002)^{* * *}\end{array}$ & $\begin{array}{l}-.206 \\
(.027)^{* * *}\end{array}$ \\
\hline Log firm size & & & $\begin{array}{c}.064 \\
(.003)^{* * *}\end{array}$ & $\begin{array}{c}.046 \\
(.002)^{* * *}\end{array}$ & $\begin{array}{l}.027 \\
(.005)^{* * *}\end{array}$ & $\begin{array}{c}.076 \\
(.0005)^{* * *}\end{array}$ & $\begin{array}{c}.068 \\
(.007)^{* * *}\end{array}$ \\
\hline No. establishments & & & $\begin{array}{c}-.002 \\
(.0006)^{* * *}\end{array}$ & $\begin{array}{c}-.0003 \\
(.0006)\end{array}$ & $\begin{array}{l}.001 \\
(.0007)^{*}\end{array}$ & $\begin{array}{c}-.00004 \\
(.00008)\end{array}$ & $\begin{array}{c}-.0002 \\
(.0008)\end{array}$ \\
\hline Foreign & & & $\begin{array}{c}.093 \\
(.012)^{* * *}\end{array}$ & $\begin{array}{l}.030 \\
(.008)^{* * * *}\end{array}$ & $\begin{array}{l}.019 \\
(.008)^{* *}\end{array}$ & $\begin{array}{c}.022 \\
(.0008)^{* * *}\end{array}$ & $\begin{array}{l}.008 \\
(.010)\end{array}$ \\
\hline Worker controls & & $\mathrm{x}$ & $\mathrm{x}$ & $\mathrm{x}$ & $\mathrm{x}$ & $\mathrm{x}$ & $\mathrm{x}$ \\
\hline Firm controls & & & $\mathrm{x}$ & $\mathrm{x}$ & $\mathrm{x}$ & $\mathrm{x}$ & $\mathrm{x}$ \\
\hline Worker fixed effects & & & & $\mathrm{x}$ & & $\mathrm{x}$ & \\
\hline Firm fixed effects & & & & & $\mathrm{x}$ & $\mathrm{x}$ & \\
\hline Spell fixed effects & & & & & & & $\mathrm{x}$ \\
\hline Obs. & 5083547 & 4992754 & 4709819 & 4709819 & 4709819 & 4709819 & 470981 \\
\hline$R^{2}$ & .101 & .487 & .57 & .913 & .678 & .18 & .927 \\
\hline
\end{tabular}

Notes: Source: Author's calculations based on Quadros de Pessoal and INE trade data. Robust standard errors, allowing for clustering at the firm level (except in specification 4, which allow for clustering at the worker level). Significance levels: *** $1 \%$; ** $5 \%$; $10 \%$. 